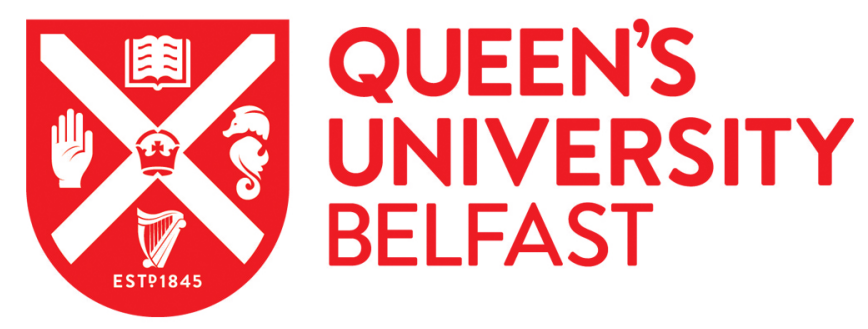

\title{
Effects of Bridge Construction and Wastewater Effluent on Phytoplankton Abundance and Sediment Geochemistry in an Atlantic Temperate Coastal Bay Since 1930
}

Karmakar, M., Leavitt, P. R., \& Patoine, A. (2019). Effects of Bridge Construction and Wastewater Effluent on Phytoplankton Abundance and Sediment Geochemistry in an Atlantic Temperate Coastal Bay Since 1930. Estuaries and Coasts, 42(2), 365-377. https://doi.org/10.1007/s12237-018-0483-7

Published in:

Estuaries and Coasts

Document Version:

Peer reviewed version

Queen's University Belfast - Research Portal:

Link to publication record in Queen's University Belfast Research Portal

Publisher rights

(C) 2018 Coastal and Estuarine Research Federation.

This work is made available online in accordance with the publisher's policies. Please refer to any applicable terms of use of the publisher.

\section{General rights}

Copyright for the publications made accessible via the Queen's University Belfast Research Portal is retained by the author(s) and / or other copyright owners and it is a condition of accessing these publications that users recognise and abide by the legal requirements associated with these rights.

Take down policy

The Research Portal is Queen's institutional repository that provides access to Queen's research output. Every effort has been made to ensure that content in the Research Portal does not infringe any person's rights, or applicable UK laws. If you discover content in the

Research Portal that you believe breaches copyright or violates any law, please contact openaccess@qub.ac.uk. 


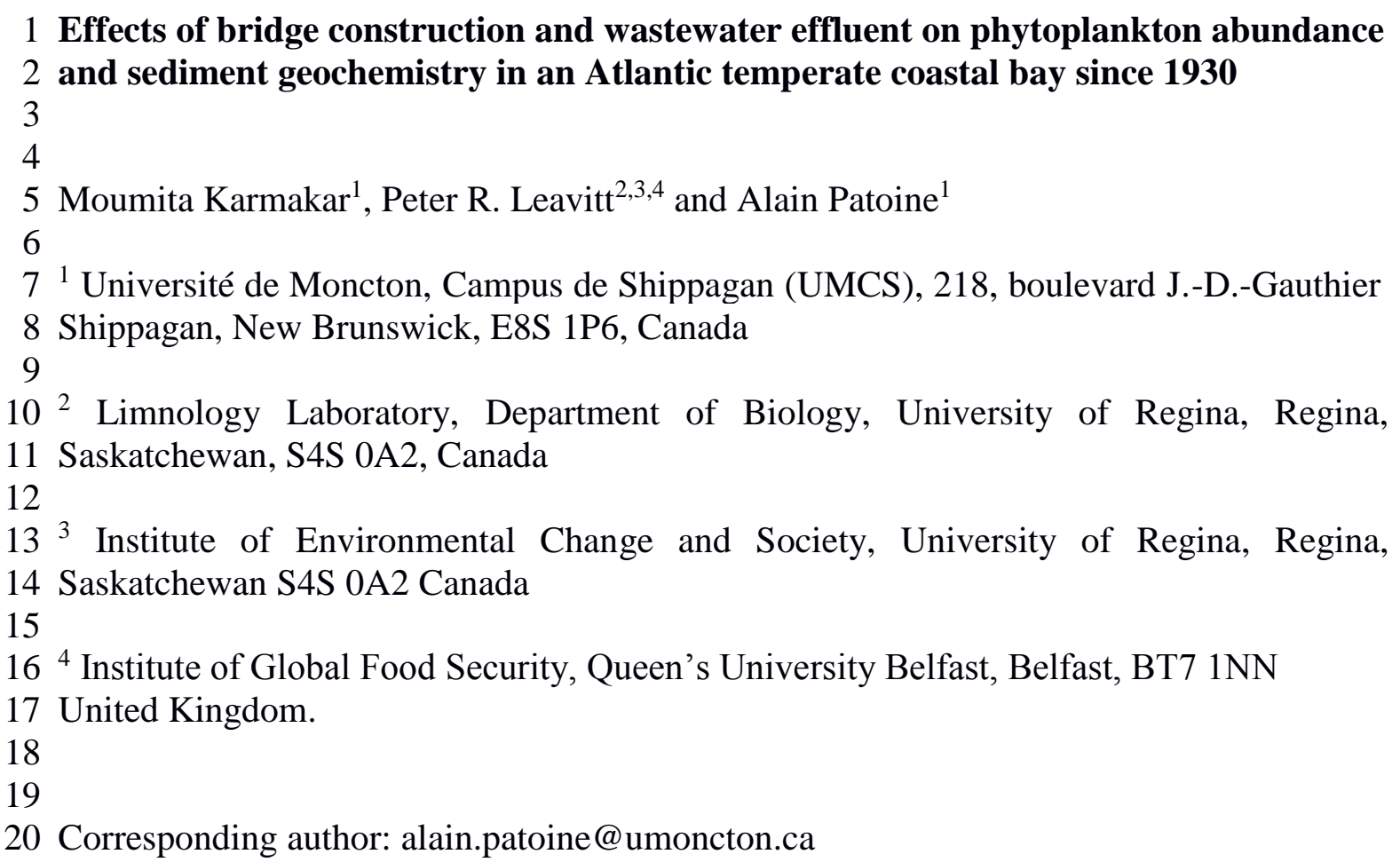

22 Keywords: Core, Eutrophication, Fossil, Paleooceanography, Phytoplankton,

23 Production, Sediment, Stable Isotopes.

\section{Acknowledgement}

26 Thanks are due to Zoraida Quinones-Rivera (IECS, Regina) for pigment analyses,

27 Julie Marcoux (Université de Moncton) for historical data and Mélanie Aubé (Coastal

28 Zone Research Institute) for comments on preliminary drafts of the manuscript. This

29 work was made possible thanks to grants from the Natural Sciences and Engineering

30 Research Council (NSERC) Discovery Grant and the New Brunswick Innovation Fund to

31 Alain Patoine. Support for PRL provided by the Canada Research Chair and Canada

32 Foundation for Innovation programs. This research was conducted on the traditional

33 territories of the Mi'Kmak First Nation. 


\section{Abstract}

2 Despite a recent proliferation of bridges in coastal zones, little is known of the

3 long-term impacts of bridge construction on phytoplankton abundance and community

4 composition in nearshore waters. Here, we used high performance liquid

5 chromatographic (HPLC) analysis to quantify historical changes in phytoplankton using

6 fossils from cores on either side of a 57 -year old bridge that reduced fetch by $76 \%$ and

7 created a discrete enclosed inner embayment. We hypothesized that phytoplankton

8 abundance should be greater in the inner bay after bridge construction due to reduced

9 hydrological flow and increased nutrient influx associated with terrestrial development

10 and more profound anoxia in the enclosed basin. As expected, primary producer

11 abundance, especially cryptophytes, increased in the inner bay during the 1950-1960s,

12 although the effect was transient despite continuous four-fold elevation in sediment

13 organic matter content $(\% \mathrm{C}, \% \mathrm{~N})$ after ca. 1960 in response to wastewater influx. The

14 pulse in cryptophytes appeared to correspond to influx of humic-rich waters derived from

15 locally-exploited peatlands, whereas the phytoplankton community of the outer basin

16 largely reflected historical variations in climate, with warmer April months associated

17 with increased abundance of diatoms and cryptophytes. Overall, sediment stable isotope

18 values in the inner basin varied in response to a complex combination of changes in

19 wastewater treatment $\left(\delta^{15} \mathrm{~N}\right)$, release of untreated fish plant effluents $\left(\delta^{15} \mathrm{~N}\right)$ and

20 connectivity with the open ocean $\left(\delta^{13} \mathrm{C}\right)$. Taken together, these findings suggest that the

21 effects of bridge construction on coastal phytoplankton production and community

22 composition operated through multiple pathways, rather than just via modifications of

23 basin hydrology. 


\section{Introduction}

2 Coastal zones support $33 \%$ of the global human population (Small and Nicholls

3 2003), a proportion which is expected to increase during the 21th century. Increasing

4 human settlement in coastal zones coincides with elevated phytoplankton abundances in

5 coastal waters, likely because terrestrial development has accelerated nutrient mass

6 transfer to nearshore waters following land clearance in the $19^{\text {th }}$ century, municipal

7 wastewaters and other point sources during 1900-1950, and continued agricultural runoff

8 (Cloern 2001, Andersen and Conley 2009). Coastal human settlement has also been

9 accompanied by the construction of bridges and causeways designed to facilitate linear

10 vehicular transportation in a landscape dissected by bays and estuaries. For example,

11 there are more than 45000 watercourse crossings in New Brunswick, Canada, a region

12 with only 0.75 million inhabitants (Jean-François Mallet, Canada Dept. Fisheries and

13 Oceans, pers. comm.).

14 In many cases, bridges are expected to modify hydrological flow regimes. When

15 water approaches a bridge, embankments redirect the flow towards the open water under

16 the bridge, resulting in increased upstream backpressure, but elevated current velocity

17 and water depth under the span due to scouring (Hamill 1999). In general, both current

18 and depth return gradually to natural values past the constriction. Flow modification due

19 to such basin closures usually occur in a region defined as approximately L/2 upstream to

20 Lx2 downstream, where $L$ is the total length of embankments (Rene Garcia 2016). As a

21 result of these modifications, most modern bridge constructions require formal

22 environmental impact assessments prior to construction (Canadian Environmental

23 Assessment Act 2012). However, despite the well documented effects of bridges and 
1 causeways on water flow, relatively little is known of their impacts on aquatic

2 ecosystems, particularly in comparison to full closure of flow by dams (Rosenberg et al.

3 1997, Li et al. 2013, Domingues et al. 2014). Like dams, bridges in coastal regions are

4 expected to reduce hydrological flow (Tas et al. 2009, Li et al. 2015), favour increased

5 sedimentation (Serieyssol et al. 2009), and favour elevated phytoplankton productivity or

6 abundance (Taylor et al. 2011, Paerl et al. 2014, Bowes et al. 2016, Brito et al. 2017).

7 Further, restriction of ocean inputs to inner bays can increase the local influence of land

8 on marine waters, including elevated depositions of terrestrial materials with unique

9 biogeochemical signatures such as C:N ratios (Sterner et al. 2008, Savage et al. 2010) and

10 carbon isotope ratio values $\left(\delta^{13} \mathrm{C}\right)$ (Peterson and Fry 1987, Hoffman and Bronk 2006, Tue

11 et al. 2012, Vaalgamaa et al. 2013).

12 Here we perform the first quantitative test of the effects of embayment closure by

13 a bridge in production and biogeochemical features of a coastal straight environment.

14 Specifically, we compared fossil profiles of pigments from phytoplankton and stable

15 isotopes of $\mathrm{C}$ and $\mathrm{N}$ in sediment cores retrieved on either side of a 776-m long bridge

16 built in $1957-1959$ that connects a $150-\mathrm{km}^{2}$ island to the mainland in Atlantic Canada.

17 We expected that sedimentation rates, fossil pigments, organic matter content, $\mathrm{C}: \mathrm{N}$ ratio,

$18 \delta^{13} \mathrm{C}$ and $\delta^{15} \mathrm{~N}$ should follow similar decadal patterns at the two coring sites until bridge

19 construction. Thereafter, we predicted that there would be a greater deposition of

20 sediments due to hydrological closure of the inner bay, resulting in elevated

21 phytoplankton abundance, changes in gross community composition and possibly

22 variation in $\mathrm{C}: \mathrm{N}$ and $\delta^{13} \mathrm{C}$ values reflecting change in the provenance of organic carbon.

23 Lastly, we hypothesized that the influence of climate variability on phytoplankton 
1 abundance may be more pronounced in the outer basin than in the inner basin, due to

2 increased distance from land use changes (cf. Savage et al. 2002). Given the general lack

3 of environmental monitoring that followed the construction of many bridges in the 1950s,

4 we rely on a paleoecological approach to better assess the potential impacts of bridge

5 construction on algal abundance. To our knowledge, this is the first study that addresses

6 the long-term impact of bridge construction on algal community structure and water

7 geochemistry.

8

9 Material and methods

10 Study area

11 Shippagan Bay is located in the Acadian Peninsula of northeast New Brunswick,

12 Atlantic Canada (Fig. 1). This part of the Eastern Lowlands Ecoregion is characterized

13 by expansive bog peatlands (Zelazny 2007) where saltmarshes represent $8 \%$ of all habitat

14 types (Hanson and Calkins 1996). Shippagan municipality harbors 2,631 inhabitants

15 (Statistics Canada 2017), with a commercial port, a marina, an oyster farm, and the

16 Aquarium and Marine Centre of New Brunswick. Shippagan Bay is $\sim 15 \mathrm{~km}$ long along

17 its north-south axis (Haigh et al. 2004) and $5 \mathrm{~km}$ wide (Duxfield et al., 2004) and can be

18 considered as a strait with a north to south orientation, separating Lamèque Island to the

19 east from the Shippagan mainland to the west (Fig. 1). The Bay communicates with the

20 Chaleur Bay to the north, the Saint-Simon Bay to the west, Lamèque Bay to the east, and

21 Shippagan harbor to the south. Shippagan Gully is located at the south-eastern limit and

22 has been heavily modified throughout the $20^{\text {th }}$ century, especially during the 1960 s- 
1 1970s, to accommodate navigation between the Chaleur Bay to the northwest and the

2 Gulf of St. Lawrence to the southeast.

3 Local tidal cycles are lagged (Logan 2012, Haigh et al. 2004), with high tide

4 reaching the northwestern part of the Shippagan bay, ebbing from Chaleur Bay, some 20

5 minutes before reaching to southeastern part of Shippagan Bay (ebbing from the Gulf of

6 St. Lawrence, Dominique Bérubé, Geological Survey Branch, New Brunswick

7 Department of Energy and Resource Development, pers. comm. 2016-05-03). In contrast,

8 tide reversal at low tide occurs at the same time (Haigh et al. 2004). Ice sheets tend to

9 accumulate on the north-western side of the bridge in winter, suggesting currents are

10 overall stronger coming in from the north-western part of the Shippagan Bay than its

11 south-eastern part. Currents through Shippagan Gully, particularly during the ebb-tide,

12 have been observed to reach velocities of over $2 \mathrm{~m} \cdot \mathrm{s}^{-1}$, while the tidal range at the inlet is

13 generally on the order of $2 \mathrm{~m}$ or less (Logan, 2012).

14

15 History of terrestrial and aquatic modifications

16 Coastal waters near Shippagan have experienced diverse human interventions,

17 including water flow restriction (gully, bridge), nearby natural resource extraction,

18 treated municipal wastewater inflow, especially in the inner, southeast bay (Online

19 Resource 1). Historically, Mi'kmak First Nations occupied the Shippagan territory before

20 first European settlers established in the $18^{\text {th }}$ century (Online Resource 1). The name

21 Shippagan itself originates from the Mi'kmak "Sepagun-chiche" ("Duck transit route").

22 In 1830, the William Fruing \& Co started its fishing activities from the Shippagan harbor, 23 while the first dock was built in 1906 (Robichaud, 1976). Transportation by train to 
1 Shippagan started 1887 and ended 1976. Industrial peat extraction commenced as early as

2 the 1940s within $1 \mathrm{~km}$ of the inner bay, while exploited surfaces expanded to $\sim 120$ ha on

3 the south shore and $\sim 673$ ha on the north shore (Online Resource 1). Peat extraction

4 involved soil drainage, vacuum extraction, but no use of fertilizer or pesticide. Cranberry

5 culture began in 1999 on 10 ha and reached 47 in 2016 (Fig. 1). During the 1880s, two

$6300 \mathrm{~m}$ jetties were constructed on either side of the gully inlet (Online Resource 1,

7 Logan, 2012). During 1965-1970, a 90 m-long jetty was added on the east side of the

8 gully (reducing inlet width), and a $600 \mathrm{~m}$-long curved breakwater was built on the west

9 side.

10 Bridge construction took place 1957-1959 at the same location as prior ferry

11 operations. Prior to construction, the shore-to-shore fetch was $\sim 776$ long; however, the

$12200 \mathrm{~m}$-long vertical-lift bridge (no pylons or piers) and over $800 \mathrm{~m}$ of causeway between

13 Lamèque Island and mainland reduced the fetch to $200 \mathrm{~m}$, equivalent to a $76 \%$ reduction

14 in hydrological connectivity. Following bridge and causeway construction, the water

15 body east of the bridge is referred to as the "inner bay" (connected to the Gulf of St.

16 Lawrence via the gully), whereas the water body west of the bridge is the "outer bay"

17 (communicating with the Chaleur Bay $10 \mathrm{~km}$ north).

18 During the 1950-1980s, up to five marine fish processing plants operated west of

19 the Shippagan port in the outer basin while a further two operated east of the bridge.

20 Operations gradually declined during the 1990s until the last fish plant closed in 2011.

21 Historically, waste and effluent from all plants were released into the bay with little or no

22 treatment. 
1 Domestic houses and industrial operations also released wastes directly into the

2 bay until 1961 (Valmond Doiron, Shippagan City Engineer, pers. comm.). Following

3 that date, the municipality of Shippagan diverted the waters from over 1600 inhabitants

4 into an urban wastewater lagoon for secondary treatment to remove organic matter before

5 releasing effluents into the inner bay near Pointe-Sauvage (Fig. 1). A second lagoon was

6 built in 1978; however, treatment effectiveness varied thereafter due to treatment failures

7 in the early 1980s, addition of aerators in 1986, further failures in 1997-1998 and

8 installation of two new aerated lagoons in 2002. Thereafter, average effluent flow from

9 the wastewater treatment plant into Baie Sauvage ("inner bay") was $76 \mathrm{~L} \cdot \mathrm{s}^{-1}$ (14 to 153 ),

10 total phosphorus $1.1 \mathrm{mg} \cdot \mathrm{L}^{-1}(0.2-2.9)$, nitrogen to phosphorus mass ratio 7.6. In 2012,

11 water temperature, salinity, turbidity, $\mathrm{pH}$ and dissolved organic carbon were comparable

12 between both stations, while total phosphorus and chlorophyll $a$ were roughly two times

13 higher in the inner bay than in the outer bay (Online Resource 2). In short, the inner bay

14 experienced a greater diversity and intensity of human interventions compared to the

15 outer bay.

16

17 Sampling

18 Sediment cores were collected in 2012, from both the outer northwest basin (35

$19 \mathrm{~cm}$ core at $\left.47^{\circ} 45^{\prime} 7.3^{\prime \prime} \mathrm{N}, 64^{\circ} 41^{\prime} 57.5^{\prime \prime} \mathrm{W}\right)$ and inner southeast site $\left(55 \mathrm{~cm}\right.$ core at $47^{\circ}$

$2044^{\prime} 17.5^{\prime \prime} \mathrm{N}, 64^{\circ} 41^{\prime} 23.5^{\prime \prime} \mathrm{W}$ ) using a polycarbonate cylinder suction corer deployed in 1

$21 \mathrm{~m}$ of water. Each core was extruded and immediately sectioned in 2-cm intervals under

22 subdued lighting. All the sediment samples were kept at $-80^{\circ} \mathrm{C}$ until further analysis. 


\section{Laboratory Methods}

2 Pigment analyses were performed using standard methods (Leavitt and Hodgson

3 2001) and fossil concentrations were expressed as nanomoles pigment $\mathrm{g}^{-1}$ organic matter

4 (nmol $\cdot \mathrm{g}^{-1} \mathrm{OM}$ ). As lutein (chlorophytes) and zeaxanthin (cyanobacteria) co-elute on this

5 HPLC system, we report them as "lutein-zeaxanthin", an indicator of potentially bloom-

6 forming taxa. We computed the molar ratio of chlorophyll $a$ to pheophytin $a$ to assess the

7 changes in preservation of pigments in sediments (Reuss et al. 2005). Overall, nine

8 pigments were identified on the basis of chromatographic position and light absorbance

9 characteristics $(350-750 \mathrm{~nm})$ relative to authentic standards, and included $\beta$-carotene and

10 chlorophyll $a$ (indicators of total biomass of primary producers), fucoxanthin and

11 diatoxanthin (mainly diatoms), echinenone (total cyanobacteria), canthaxanthin (colonial

12 cyanobacteria), chlorophyll $b$ (chlorophytes), lutein-zeaxanthin (chlorophytes and total

13 cyanobacteria), and alloxanthin (cryptophytes). Taxonomic affiliations followed those

14 established by Leavitt and Hodgson (2001) and Paerl et al. (2003).

15 Lead-210 activities were measured at GEOTOP laboratories (Université du

16 Québec à Montreal). Measurements were based on alpha counting of the activity of ${ }^{210} \mathrm{Po}$

$17\left(\mathrm{t}_{1 / 2}=138.4\right.$ days, alpha $\left.=5.30 \mathrm{MeV}\right)$, which is a daughter isotope of ${ }^{210} \mathrm{~Pb}$. Counting was

18 performed in a silicon surface barrier alpha spectrometer (EGG and ORTEC type 576A).

19 Chemical extraction, counting efficiency and estimation of uncertainties followed Not et

20 al. (2008). Counting uncertainty averaged 6\% (range 4-8\%), comparable to Turner et al.

21 (2006). Supported ${ }^{210} \mathrm{~Pb}$ was estimated as the bottom three determinations of ${ }^{210} \mathrm{~Pb}$

22 activity (Binford 1990). The Constant Rate of Supply (CRS) model was chosen to 
1 estimate sediment age because sedimentation rates are anticipated to have varied

2 throughout the $20^{\text {th }}$ century.

3 Carbon and nitrogen isotope analyses were performed using a ThermoQuest (F-

4 MAT) Delta ${ }^{\text {PLUS }} \mathrm{XL}$ isotope ratio mass spectrometer equipped with continuous flow (Con

5 Flo II) unit and an automated Carlo Erba elemental analyzer as an inlet device (Leavitt et

6 al. 2006). Stable nitrogen (N) and carbon (C) isotopic compositions $\left(\delta^{15} \mathrm{~N}, \delta^{13} \mathrm{C}\right)$ were

7 expressed in the conventional $\delta$-notation in units of per mil (\%) deviation from

8 atmospheric $\mathrm{N}_{2}$ and organic $\mathrm{C}$ standards previously calibrated against authentic Vienna

9 Pee Bee Belemnite. Sample reproducibility was $\sim 0.11 \%$ and $0.10 \%$ for $\delta^{15} \mathrm{~N}$ and $\delta^{13} \mathrm{C}$

10 determinations.

11

12 Climate data

13 Climate data (precipitation and air temperature) were downloaded from the

14 Government of Canada Climate Web site (http:// climate.weather.gc.ca/). Only two

15 climate stations in New Brunswick recorded daily data throughout most of the twentieth

16 century: Bathurst (station no 8100500) situated $75 \mathrm{~km}$ west of Shippagan, and Moncton

17 (station no 8103100) situated $185 \mathrm{~km}$ south. The Moncton data series was the longest and

18 most consistent climate data series and was shown to be an acceptable surrogate of

19 climatic conditions prevailing in the northeast of the province (Ady and Patoine 2016).

20

21 Numerical analysis

22 Principal component analysis (PCA) was used to represent temporal changes in

23 the pigment community and help identify periods of rapid change (Legendre and 
1 Legendre 1998: 692). Redundancy analysis (RDA) was performed for each core with an

2 environmental data set comprised of 10 climatic variables (average monthly air

3 temperatures and precipitations for the months of April-August). Selection of

4 environmental variables followed Blanchet et al. (2008), using 1000 permutations.

5 Because the temporal resolution of climatic data (yearly) was finer than core age

6 estimates, we aggregated the climatic data into periods that matched the particular age

7 profile of each core (Table 1).

8 Graphics were generated with Tilia v.2.0.2 and Origin (v 6.1). Principal

9 component analysis (PCA) was performed with CANOCO v.5 (ter Braak and Šmilauer,

10 2002). Redundancy analysis (RDA) was performed in $\mathrm{R}$ version 3.1.1 (R Core Team

11 2014) with functions prcomp, rda, ordistep, forward.sel (Blanchet et al., 2008).

12

\section{Results}

\section{Sediment chronology}

15 The ${ }^{210} \mathrm{~Pb}$ activity of the outer basin core declined continuously over the first 10

$16 \mathrm{~cm}$ before reaching the background levels (Fig. 2a). In contrast, the ${ }^{210} \mathrm{~Pb}$ activity profile

17 of the inner basin site was relatively constant over first $10 \mathrm{~cm}$, followed by declining

18 activity to a baseline at $25 \mathrm{~cm}$ (Fig. 2b). Continuous Rate of Supply (CRS) calculations

19 suggested that both cores could be dated back to ca. 1935 CE (Figs. 2c, d, Table 1).

20 Extrapolation of sediment ages for the outer bay suggests that $9 \mathrm{~cm}$ depth represented ca.

$211893 \mathrm{CE}$ at that site.

22 In the outer bay, sedimentation rate for the entire dated period 1935-2012

23 averaged $1.6 \mathrm{~mm} \cdot \mathrm{y}^{-1}( \pm 0.3$ st. error $)$; it increased to $1.8 \pm 0.2 \mathrm{~mm} \cdot \mathrm{y}^{-1}$, for the period post 
11957 (after the bridge construction). It was not possible to accurately estimate early

2 sedimentation rates before bridge construction in the outer bay because only one age

3 estimate was available prior to 1957. A similar increasing trend was noticed in the inner

4 bay where sedimentation values increased from $1.7 \pm 0.1 \mathrm{~mm} \cdot \mathrm{y}^{-1}$ (pre-1960) to $1.9 \pm 0.1$

$5 \mathrm{~mm} \cdot \mathrm{y}^{-1}$ (post-1957).

6

7 Sediment geochemistry

8 Average organic matter was relatively low (5\%) and did not vary substantially

9 through time in the outer basin sediments (Fig. 3). While initially similar to the outer

10 basin (ca. 7\%), organic matter content in the inner bay increased abruptly after ca. 1950

11 to $36 \%$ and remained higher than 20\% thereafter (Fig. 4). Overall, C:N ratios were

12 slightly lower in the outer basin (11) than in the inner basin (13) (Fig. 5a), although,

13 temporal variability in C:N was generally high at both sites with few distinct trends

14 beyond a transient peak ca. 1990 in the inner basin.

15 Overall, $\delta^{13} \mathrm{C}$ values were similar in both basin ( -18-19\%), exhibiting only

16 minor ( $\sim 2 \%$ ) variations through the past 100 years (Fig. $5 b)$. The $\delta^{15} \mathrm{~N}$ values of the outer

17 basin sediments fluctuated within a narrow range ( 4.2 to $4.6 \%$ ) throughout the dated

18 interval of the core, whereas that of the inner basin decreased from $>5 \%$ in the 1970 s to

$19 \sim 4.4 \%$ in the 2000s (Fig. 5c). Temporal variability of $\delta^{13} \mathrm{C}$ and $\delta^{15} \mathrm{~N}$ was greater in the

20 inner bay than in the outer bay (Fig. 5d). 


\section{Phytoplankton abundance}

2 Analysis of $\beta$-carotene concentrations from the outer-basin core suggests that total

3 phytoplankton abundances were generally greater during the $19^{\text {th }}$ century than the $20^{\text {th }}$

4 century (Fig. 3). Similar declining trends were observed for pigments from cyanobacteria

5 (echinenone, lutein-zeaxanthin), especially colonial forms (canthaxantin), with the latter

6 not being detected after the 1890s. In contrast, alloxanthin (cryptophytes) and

7 diatoxanthin (diatoms) showed trends towards higher abundances after ca. 1950. Overall,

8 the chl $a$ to pheophytin $a$ ratio (indicating preservation environment) was stable and low

$9(0.3)$ prior to the $20^{\text {th }}$ century, and doubled thereafter (Fig. 3), suggesting more favorable

10 preservation condition in recent times. In contrast, fucoxanthin and chl-a showed

11 exponential increases with time, a pattern that likely reflects the chemical instability of

12 these compounds relative to other biomarkers (reviewed in Leavitt and Hodgson 2001).

13 Unlike the outer basin core, concentration of most pigments in the inner basin tended to

14 peak in the 1950s-1960s, at 9-11 cm depths (Fig. 4) but otherwise showed little trend

15 beyond a secondary transient peak ca. 1988. This latter event also coincided with a brief

16 rise in the chl $a$ :pheophytin $a$ ratio indicative of better pigment preservation conditions.

17 Principal component analysis (PCA) of the outer basin site suggests a shift in

18 phytoplankton composition from a $19^{\text {th }}$ century community with abundant cyanobacteria

19 (canthaxanthin, echinenone) to $20^{\text {th }}$ century assemblage with more eukaryotes (Fig. 6a).

20 In contrast, the inner basin was characterized by periods of higher phytoplankton

21 abundance (years 1944, 1963, 1988, 2005 on axis I) alternating with periods of lesser

22 abundance $(1978,1998)$ (Fig. 6b). When data from both basins are co-ordinated in a

23 single PCA (Fig. 6c), inner basin phytoplankton community from 1944, 1963, 1988 
1 formed a distinct cluster along PCA axis I, representing elevated abundance of

2 chlorophytes (chl-b) and cryptophytes (alloxanthin).

3 Redundancy analyses of the outer basin data showed that greater concentrations of

4 the carotenoids diatoxanthin (diatoms) and alloxanthin (cryptophytes) were associated

5 with higher April temperatures after the 1980s (Fig. 7, \% inertia explained=62\%,

$6 \mathrm{p}=0.04)$. In contrast, none of the 10 climatic variables were significant $(p>0.05)$

7 predictors of changes in fossil pigment assemblages in the inner core.

8

9 Discussion

10 Despite close spatial proximity of both coring sites $(1.7 \mathrm{~km})$, sediment cores

11 revealed different patterns of decadal variations of pigment concentration and

12 biogeochemistry, corresponding to variations in infrastructure development, basin-

13 specific hydrology, and land use. For example, the inner basin core showed greater $\delta^{13} \mathrm{C}$

14 and $\delta^{15} \mathrm{~N}$ temporal variability (Fig. 5d) in response to adjacent coastal development,

15 whereas pigment assemblages in the outer basin appeared to respond mostly to changes

16 in climate (Fig. 7). Overall, patterns of variation did not support the central hypothesis

17 that bridge construction resulted in a major change in basin hydrology, or phytoplankton

18 abundance (Figs. 3, 4) despite concomitant changes in sediment geochemistry.

19 Studies that have examined the spatial variability of stratigraphies among cores

20 extracted from a single coastal water body tend to show that among-core variability is

21 low relative to within-core (temporal) variability when cores are collected a few meters

22 apart (Chen et al. 2001) or at distances of $1 \mathrm{~km}$ (Cooper 1995) and up to $10 \mathrm{~km}$ (Savage

23 2005, Turner et al. 2006), particularly in the absence of strong riverine influence (see 
1 Petersen et al. 2003). Instead, given the absence of large freshwater inflows, differences

2 among cores in the same coastal water body reveal the unique patterns of landuse and

3 climate at distances of 20-30 km (Andrén 1999, Li et. al. 2011). Consequently, given that

4 our cores are each $<1 \mathrm{~km}$ from the bridge (total $1.7 \mathrm{~km}$ apart), we presume that

5 differences in sites reflect mainly the effects of major disruption to hydrology or

6 geochemistry arising in part from bridge construction, although we recognize that further

7 research will be required at other bridges to confirm our novel findings (see below).

8

9 Effects of basin development on sediment geochemistry

10 Sedimentation rates estimated herein $(0.9-2.2 \mathrm{~mm} / \mathrm{y})$ are similar to those reported

11 for other estuarine or coastal environments (Chen et al. 2001, Turner et al. 2006, Li et al.

12 2011, Ady and Patoine 2016). As expected, we observed slightly higher sedimentation

13 rates in the inner bay than in the outer bay, likely reflecting both reduced flushing of

14 particulate matter to the open ocean following the 1957-1959 bridge construction and

15 increased resuspension of local materials due to dredging and modification of the gully

16 during the 1960s and 1970s. Onset of industrial peat extraction on both sides of the inner

17 bay (Fig. 1) as early as the 1940s (Online Resource 1) could also have contributed to

18 increase the particulate mass influx to the inner bay, due to increased soil erosion and loss

19 to adjacent surface waters (Clément et al. 2009). Finally, transient increases in

20 phytoplankton abundance (Fig. 4, see below) within the inner site may have favored

21 increased sediment deposition.

22 Bridge construction altered the deposition of organic matter in the inner basin

23 (Fig. 4). Specifically, organic matter content increased permanently after bridge 
1 construction in the 1950s, but was unchanged in the outer bay. While the organic content

2 values of 4-7\% observed in the outer bay are comparable to those reported for

3 subtropical, agricultural-dominated coastal watershed estuaries in Florida (Turner et al.

4 2006) and eastern Australia (Logan et al. 2011), those for the inner bay post-1959 were

5 roughly double values typical of nearshore waters, reaching 20-36\% (Fig. 4). Although

6 mechanisms are difficult to fully confirm, these changes likely arose because of the

7 combined effect of wave erosion of excavated peatlands (Zelazny, 2007), long-term

8 changes in wastewater inputs (Online Resource 1), and elevated primary production (Fig

9 4). Such a two-fold increase of organic matter content is similar to that observed in other

10 coastal waters experiencing wastewater inputs, such as New Bedford Harbour (Chmura et

11 al. 2004).

12 Throughout the outer bay core, the $\mathrm{C}: \mathrm{N}$ ratios (10-12) of whole sediments

13 reflected the importance of coastal algae $(<8$, Kendall et al. 2001, Ock and Takemon

14 2014) and carbonate deposition (Gattuso et al. 1998, Savage et al. 2010). In the inner

15 bay, the lowest values $(\sim 12)$ were observed about the same time as the bridge

16 construction and the algal peak, supporting the idea that the $\mathrm{C}: \mathrm{N}$ ratio might reflect the

17 importance of algal biomass to particulate matter. The C:N peak of 15 observed ca. 1990

18 in the inner basin could reflect an increased contribution from inorganic sediments

19 following the 1989 and 1993 channel dredging (Online Resource 1).

20 Sediment $\delta^{13} \mathrm{C}$ values recorded herein (-20 to $-18 \%$ ) were higher than those

21 reported in previous paleoecological studies (-32 to $-20 \%)$ set in coastal or estuarine

22 environments (Turner et al. 2006, Savage et al. 2010, Jin et al. 2010, Logan et al. 2011).

23 The extensive saltmarshes and eelgrass beds that characterize the Shippagan region to 
1 this day (Hanson and Calkins 1996) may explain the exceptionally enriched ${ }^{13} \mathrm{C}$ signal

2 observed throughout the core, as seagrasses are known to undergo little carbon

3 fractionation relative to typical $\mathrm{C} 3$ terrestrial plants, despite their common use of ribulose

4 1,5-bisphosphate (RuBP) carboxylase to fix $\mathrm{CO}_{2}$ (Benedict et al., 1980). Sedimentary

$5 \delta^{13} \mathrm{C}$ values as high as -20 to $-18 \%$ have also been reported for eastern north America,

6 but only prior to intensified coastal development ( $19^{\text {th }}$ century, Chmura et al. 2004).

7 Hence, the continued importance of eelgrass in Shippagan Bay may explain the elevated

$8 \delta^{13} \mathrm{C}$ signal.

9 The $\delta^{13} \mathrm{C}$ temporal variability was as great on both side of the bridge (Fig. 5b),

10 such that it is difficult to interpret peaks and troughs as the result of human-made

11 modification to the gully. However, slightly higher $(\sim 1 \%) \delta^{13} \mathrm{C}$ values in the inner bay

12 core sediments relative to those from the outer bay are consistent with the inner bay

13 core's greater proximity to open oceanic waters ( $3 \mathrm{~km}$ to the gully) relative to that of the

14 outer bay core ( $10 \mathrm{~km}$ to the Chaleur Bay). Indeed, the $\delta^{13} \mathrm{C}$ signature of sediments

15 typically increases in coastal zones as one moves closer to the open ocean, where the

16 importance of atmospherically-derived dissolved inorganic carbon increases $\left(\delta^{13} \mathrm{C} \sim\right.$

$170 \%$ ), to the detriment of $\mathrm{CO}_{2}$ derived from respiratory processes (Martineau et al. 2004,

18 Turner et al. 2006, Hoffman and Bronk 2006, Vaalgamaa et al. 2013, Kaiser et al. 2014).

19 Hence, the $\delta^{13} \mathrm{C}$ separation between inner and outer bay may reflect proximity to oceanic

20 inorganic carbon sources.

21 In both cores, maximum $\delta^{15} \mathrm{~N}$ values were reached during the 1950s-1960s,

22 coincident with the inner bay wastewater treatment plant startup and the period of peak

23 activity of the outer bay fish plants (Online Resource 1). Indeed, coastal sites receiving 
1 treated wastewaters (Savage et al. 2010) or fish farming effluents (Vaalgamaa et al. 2013)

2 usually display a slightly higher $\delta^{15} \mathrm{~N}$ signature relative to reference sites. These results

3 are also consistent with high N-loading figures from seafood processing plants in the

4 Shippagan-Lamèque area (McIver et al. 2015). The important post-1970 $\delta^{15} \mathrm{~N}$ decline in

5 the inner bay could be the result of the municipal sewer pipe network becoming

6 increasingly leaky (accounting for the high effluent flow of $76 \mathrm{~L} \cdot \mathrm{s}^{-1}$ in the $2000 \mathrm{~s}$, Online

7 Resource 1), with increasing amounts of groundwater seeping into the system, diluting

8 the wastewater and giving the final effluent a low $\delta^{15} \mathrm{~N}$ signature, typical of groundwater

9 set in undeveloped areas (Komor and Anderson 1993). The post-1970 $\delta^{15} \mathrm{~N}$ decline

10 observed in the outer bay is consistent with the gradual shutdown of fish plants during the

11 1990s.

12

13 Effects of basin development on algal assemblages

14 The range of pigment concentration reported herein $(10-500 \mathrm{nmol} / \mathrm{g} \mathrm{OM})$ was

15 comparable to that reported for other coastal zones (Chen et al. 2001; Bianchi et al. 2002;

16 Reuss et al. 2005; Savage et al. 2010; Ady and Patoine 2016). Similarly, ratios of labile

17 precursor-stable product compounds (Chl $a$ : pheophytin $a$ ) observed here $(0.2-2.2)$ were

18 comparable to those reported in other estuarine studies (Reuss et al. 2005; Savage et al.

19 2010) and suggested few changes which would obscure interpretation of the fossil

20 pigment record. Consequently, the observation that algal abundance in the inner bay

21 increased only briefly after bridge construction (Fig. 4) suggested that, contrary to

22 expectations, there was no sustained increase in algal abundance as result of hydrologic

23 closure of the inner embayment. Although fossil pigment concentration exhibited a 
1 secondary peak in the late 1980s, this event coincides with similar variations in sediment

2 preservation (as chl $a$ :pheophytin ratio), suggesting a sudden but transient improvement 3 in pigment preservation conditions.

4 Overall, algal abundance varied only modestly, despite changes in water 5 circulation (bridge construction, gully maintenance), nutrient pollution (treated sewage 6 inputs) and land use practices (peat extraction). Similar to Brito et al. (2017), we found 7 that bridge construction was associated with increased algal biomass, an effect the 8 authors attribute to the decreased flow and increased nutrient accumulation on the 9 landward side of the bridge. However, in our case, the effect was mild and short-lived 10 (1950s-1960s), possibly because both sides of the bridge remain connected to oceanic 11 water masses (Chaleur Bay to the northwest, Gulf of St. Lawrence to the southeast) and 12 there were few significant sources of freshwater to the inner basin (cf. Ady and Patoine 13 2016, Petersen et al. 2003). Although speculative, we suggest that limited algal response 14 may demonstrate that some level of water replenishment from the ocean may have been 15 maintained, despite restriction following the bridge construction.

16 Several paleooceanographic studies of estuarine environments report increased 17 diatom biomass following wastewater inputs (Savage et al. 2010 and references therein). 18 In contrast, we report episodic increases of chlorophytes and cryptophytes post-1959 in 19 the inner bay (Figs. 4, 6b). Although speculative, we feel that the rise in these groups, 20 normally a minor component of marine phytoplankton assemblages (Borges Mendes et 21 al. 2017), may mainly reflect changes in the influx of highly colored humic substances,

22 compounds which favor cryptophytes in both lakes (Jones 2000, Klug 2002, Waters et al. 23 2012) and coastal settings (Kimmerer et al. 2012). Here, the extensive peat extraction 
1 activities that started in the 1940s-1950s on both terrestrial sides of the inner bay (Online

2 Resource 1) could have contributed to humic substances export to the inner bay (Surette

3 et al. 2002) and favored mixotrophic production in response to change in organic matter

4 characteristics.

5 Overall, if bridge construction favored algal abundance through reduced

6 hydrodynamics, it only did so transiently during the 1960s. Instead, modification to the

7 gully during the 1960s and 1970s could have shifted the hydrodynamic regime to yet

8 another state, not as favorable to algal growth, accounting for declining algal levels in

9 more recent times (except for chlorophytes and cryptophytes).

10 Bridges spanning coastal bays and estuaries are common in Atlantic Canada. For

11 example, there are at least 96 bridges across 30 estuaries within a $50 \mathrm{~km}$ by $200 \mathrm{~km}$

12 region from Shippagan south to Shediac, New Brunswick. These bridges span river

13 widths varying from 25 to $850 \mathrm{~m}$ (median $100 \mathrm{~m}$, inter-quartile range $70-230 \mathrm{~m}$ ).

14 Although less common than spans over estuaries, bridges also overpass straits in the

15 regional coastline, with 11 spans over straits within three Canadian Atlantic provinces.

16 These strait bridges cross $80 \mathrm{~m}$ to $12900 \mathrm{~m}$ of water (inter-quartile range 267 to $1313 \mathrm{~m}$ ),

17 including the Shippagan bridge (776 $\mathrm{m}$ of natural fetch). Nine of these strait bridges

18 connect mainland to islands each with unique degrees of residential, commercial or

19 industrial development. Future studies should compare historical changes in marine

20 production to estimate the regional impacts of continued human population growth and

21 bridge construction. Based in this study, we anticipate that impacts may only be evident

22 when strait bridges restrict circulation more than $75 \%$, or less for bridges spanning bays

23 or estuaries (cf. Brito et al. 2017). 


\section{Effects of climate on coastal production}

3 April temperature was a significant predictor of changes in fossil pigment

4 assemblages, but only in the outer basin site ( $p=0.04$, Fig. 7$)$. The positive effect of

5 increasing temperature on phytoplankton biomass has already been reported for other

6 coastal systems (e.g., Rodrigues and Pardal 2015), although factors related to land-use

7 can dominate over climatic effects. Indeed, Savage et al. (2010) show that, while climatic

8 variables (including annual total precipitation, annual average temperature) become more

9 important correlates of estuarine phytoplankton community composition in recent years

10 (1975-2000) relative to prior periods (1950-2000, 1880-2000), land-use factors

11 (agriculture and wastewater treatment plant activities) remain stronger drivers at all time-

12 scales examined. Similarly, we could detect the influence of warmer spring seasons on

13 phytoplankton biomass (Fig. 7), but only at the site less impacted by land activities (outer

14 bay), suggesting that climatic effects on biota is easily overshadowed by local alterations

15 of the physical environment (Savage et al. 2002).

16 The shift from cyanobacteria to eukaryotes with warmer spring temperature in the

17 outer bay (Fig. 7) is contrary to expectations based on laboratory experiments showing

18 that cyanobacteria have a higher temperature growth optimum than eukaryotic groups of

19 algae and should thus be favored in warmer environments (Paerl et al. 2014). While some

20 field studies do confirm the prevalence of cyanobacteria in warmer waters (Paerl et al.

21 2011, Carstensen et al. 2015), it is not universal (Phlips et al. 2010) and also depends on

22 hydrological features, nutrient ratios, and irradiance regimes (Kahru et al. 1994; Paerl et

23 al. 2011). 


\section{Conclusions}

3 Here we show for the first time that bridge and causeway constructions produced

4 few sustained changes in algal abundance or composition at the scale of decades (Figs. 4,

5 8). Instead, it appears that sewage input to the inner bay likely had a paramount effect on

6 water chemistry and biology as evidenced by the sharp decline in sedimentary $\delta^{15} \mathrm{~N}$ after

7 initial wastewater treatment plant influx and by the sustained increase in organic content

8 of sediments. In contrast, variations in algal abundance in the outer bay, where human

9 perturbations were less likely to be propagated, were better associated with historical

10 variations in climate, specifically temperature.

11 Based on this study, we predict that bridge constructions will have mild impacts

12 on phytoplankton assemblages wherever both sides of the bridge maintain a hydrological

13 connexion to marine water masses, but that damages could occur when infrastructure

14 inhibits oceanic exchange by closing more than $75 \%$ of the embayment mouth. Given

15 the dearth of similar studies on bridge impacts (e.g., Brito et al. 2017), we suggest that

16 future work should quantify how the magnitude of effects on primary production may

17 vary with the degree of flow restriction. 


\section{References}

2 Ady, F. D. and A. Patoine. 2016. Impacts of land use and climate variability on algal

3 communities since $\sim 1850 \mathrm{CE}$ in an oligotrophic estuary in northeastern New

4 Brunswick, Canada. Journal of Paleolimnology 55: 151-165.

5 Andersen, J. H., and D. J. Conley. 2009. Eutrophication in coastal marine ecosystems:

6 towards better understanding and management strategies. Hydrobiologia 629: 1-4.

7 Andrén, Elinor. 1999. Changes in the composition of the diatom flora during the last

8 century indicate increased eutrophication of the Oder estuary, south-western Baltic

$9 \quad$ Sea. Estuarine, Coastal and Shelf Science 48: 665-676.

10 Benedict, C. Roy, William W. L. Wong, and Joshua H. H. Wong. 1980. Fractionation of 11 the stable isotopes of inorganic carbon by seagrasses. Plant Physiology 65: 51212517.

13 Bianchi, T.S., E. Engelhaupt, B.A. McKee, S. Miles, R. Elmgren, S. Hajdu, C. Savage, 14 and M. Baskaran. 2002. Do sediments from coastal sites accurately reflect time 15 trends in water column phytoplankton? A test form Himmerfjarden Bay (Baltic Sea 16 proper). Limnology and Oceanography 47: 1537-1544.

17 Binford, M.W., 1990. Calculation and uncertainty analysis of ${ }^{210} \mathrm{~Pb}$ dates for PIRLA 18 project lake sediment cores. Journal of Paleolimnology 3: 253-267

19 Blanchet, F. Guillaume, Pierre Legendre, and Daniel Borcard. 2008. Forward selection of 20 explanatory variables. Ecology 89: 2623-2632.

21 Borges Mendes, Carlos Rafael, Clarisse Odebrecht, Virginia Maria Tavano, and Paulo

22 Cesar Abreu. 2017. Pigment-based chemotaxonomy of phytoplankton in the Patos

23 Lagoon estuary (Brazil) and adjacent coast. Marine Biology Research 13: 22-35. 
1 Bowes, M. J., M. Loewenthal, D. S. Read, M. G. Hutchins, C. Prudhomme, L. K.

2 Armstrong, S. A. Harman, H. D. Wickham, E. Gozzard, and L. Carvalho. 2016.

3 Identifying multiple stressor controls on phytoplankton dynamics in the River

4 Thames (UK) using high-frequency water quality data. Science of The Total

$5 \quad$ Environment 569-570: 1489-1499.

6 Brito, Ana C., Teresa Silva, Carolina Beltrán, Paula Chainho, and Ricardo F. de Lima.

7 2017. Phytoplankton in two tropical mangroves of São Tomé Island (Gulf of

8 Guinea): A contribution towards sustainable management strategies. Regional

$9 \quad$ Studies in Marine Science 9: 89-96.

10 Canadian Environmental Assessment Act, 2012. Retrieved from the Justice Laws

11 Website http://laws-lois.justice.gc.ca/eng/acts/C-15.21/index.html

12 Carstensen, Jacob, Riina Klais, and James E. Cloern. 2015. Phytoplankton blooms in

13 estuarine and coastal waters: Seasonal patterns and key species. Estuarine Coastal

$14 \quad$ and Shelf Science 162: 98-109.

15 Chen, N., Bianchi, T.S., McKee, B.A., Bland, J.M., 2001. Historical trends of hypoxia on

16 the Louisiana Shelf: application of pigments as biomarkers. Organic geochemistry

$17 \quad 32: 543-561$.

18 Chmura, G.L., Santos, A., Pospelova, V., Spasojevic, Z., Lam, R., Latimer, J.S., 2004.

19 Response of three paleo-primary production proxy measures to development of an

20 urban estuary. Science of The Total Environment 320: 225-243. 
1 Clément, Marie, André St-Hilaire, Daniel Caissie, Alyre Chiasson, Simon Courtenay, and

2 Peter Hardie. 2009. An evaluation of mitigation measures to reduce impacts of peat

3 harvesting on the aquatic habitat of the East Branch Portage River, New

$4 \quad$ Brunswick, Canada.” Canadian Water Resources Journal 34: 441-452.

5 Cloern, J.E. 2001. Our evolving conceptual model of the coastal eutrophication problem.

$6 \quad$ Marine Ecology Progress Series 210: 223-53.

7 Cooper, Sherri Rumer. 1995. Chesapeake Bay Watershed Historical Land Use: Impact on

$8 \quad$ Water Quality and Diatom Communities. Ecological Applications 5: 703-723.

9 Domingues, Rita B., Ana B. Barbosa, and Helena M. Galvão. 2014. River damming leads

10 to decreased phytoplankton biomass and disappearance of cyanobacteria blooms.

11 Estuarine, Coastal and Shelf Science 136: 129-138.

12 Duxfield, A., Clarke, J.E.H., Martin, B.A., 2004. Combining multiple sensors on a single

13 platform for nearshore mapping, Canadian Hydrographic Conference, Ottawa.

14 http://www.omg.unb.ca/omg/papers/CHC2004_duxfield.

15 Gattuso, J.-P., M. Frankignoulle, and R. Wollast. 1998. Carbon and carbonate

16 metabolism in coastal aquatic ecosystems. Annual Review of Ecology and

$17 \quad$ Systematics 29: 405-434.

18 Haigh, Susan, John Hughes Clark, and Joël Chassé. 2004. Numerical modelling of

19 Shippagan Bay.” http://www.omg.unb.ca/ haigh/shippagan.html.

20 Hamill, L. 1999. Bridge Hydraulics. London: CRC Press.

21 Hanson, A. R., and Calkins, L. 1996. Wetlands of the Maritime Provinces: revised

22 documentation for the wetlands inventory. Environment Canada, Canadian Wildlife

23 Service, Atlantic Region. 
1 Hoffman, J. C., and D. A. Bronk. 2006. Interannual variation in stable carbon and

2 nitrogen isotope biogeochemistry of the Mattaponi River, Virginia. Limnology and

3 Oceanography 51: 2319-2332.

4 Jin, Haiyan, Jianfang Chen, Huanxin Weng, Hongliang Li, Weiyan Zhang, Jie Xu,

5 Youcheng Bai, and Kui Wang. 2010. Variations in paleoproductivity and the

6 environmental implications over the past six decades in the Changjiang Estuary."

$7 \quad$ Acta Oceanologica Sinica 29: 38-45.

8 Jones, Roger I. 2000. Mixotrophy in planktonic protists: an overview. Freshwater

9 Biology 45: 219-226.

10 Kahru, M., U. Horstmann, and O. Rud. 1994. Satellite detection of increased

11 cyanobacteria blooms in the Baltic Sea: natural fluctuation or ecosystem change?

12 Ambio 23: 469-472.

13 Kaiser, David, Daniela Unger, and Guanglong Qiu. 2014. Particulate organic matter

14 dynamics in coastal systems of the Northern Beibu Gulf. Continental Shelf

$15 \quad$ Research 82: 99-118.

16 Kendall, Carol, Steven R. Silva, and Valerie J. Kelly. 2001. Carbon and nitrogen isotopic

17 compositions of particulate organic matter in four large river systems across the

18 United States. Hydrological Processes 15: 1301-1346.

19 Kimmerer, Wim J., Alexander E. Parker, Ulrika E. Lidström, and Edward J. Carpenter.

20 2012. Short-term and interannual variability in primary production in the low-

21 salinity zone of the San Francisco Estuary. Estuaries and Coasts 35: 913-29. 
1 Klug, Jennifer L. 2002. Positive and negative effects of allochthonous dissolved organic

2 matter and inorganic nutrients on phytoplankton growth. Canadian Journal of

$3 \quad$ Fisheries and Aquatic Sciences 59: 85-95.

4 Komor, Stephen C., and Henry W. Anderson. 1993. Nitrogen isotopes as indicators of

5 nitrate sources in Minnesota sand-plain aquifers. Ground Water 31: 260-70.

6 Leavitt, P.R., C.S. Brock, C. Ebel, and A. Patoine. 2006. Landscape-scale effects of

7 urban nitrogen on a chain of freshwater lakes in Central North America. Limnology

$8 \quad$ and Oceanography 51: 2262-2277.

9 Leavitt, P.R., Hodgson, D.A., 2001. Sedimentary pigments. In: Smol, J.P., Birks, H.J.B.,

10 Last, W.M. (Eds.), Tracking environmental change using lake sediments, terrestrial,

11 algal, and siliceous indicators, vol. 3. Kluwer Academic Publishers, Dordrecht, The

12 Netherlands, pp. 295-325.

13 Legendre, P., and L. Legendre. 1998. Numerical Ecology. New York: Elsevier.

14 Li, Jinpeng, Shikui Dong, Shiliang Liu, Zhifeng Yang, Mingchun Peng, and Chen Zhao.

15 2013. Effects of cascading hydropower dams on the composition, biomass and

16 biological integrity of phytoplankton assemblages in the middle Lancang-Mekong

17 River. Ecological Engineering 60:316-24.

18 Li, Junlong, Binghui Zheng, Xupeng Hu, Yiming Wang, Ye Ding, and Fang Liu. 2015.

19 Terrestrial input and nutrient change reflected by sediment records of the

20 Changjiang River Estuary in recent 80 years. Acta Oceanologica Sinica 34: 27-35.

21 Li, X., T. S. Bianchi, Z. Yang, L. E. Osterman, M. A. Allison, S. F. DiMarco, and G.

22 Yang. 2011. Historical trends of hypoxia in Changiiang River Estuary: applications

23 of chemical biomarkers and microfossils. Journal of Marine Systems 86: 57-68. 
1 Logan, Brendan, Kathryn H. Taffs, Bradley D. Eyre, and Atun Zawadski. 2011.

2 Assessing changes in nutrient status in the Richmond River estuary, Australia,

3 using paleolimnological methods. Journal of Paleolimnology 46: 597-611.

4 Logan, Seth James. 2012. Morphological and Numerical Modeling of a Highly Dynamic

5 Tidal Inlet at Shippagan Gully, New Brunswick. Ottawa: University of Ottawa.

6 https://www.ruor.uottawa.ca/bitstream/10393/20527/1/Logan_Seth_James_2012_th

7 esis.pdf.

8 Mallet, Patrice-Éloi. 2012. Shippagan: c'est tout simplement l'Acadie. Québec: Éditions

9 GID.

10 Martineau, Christine, Warwick F. Vincent, Jean-Jacques Frenette, and Julian J. Dodson.

11 2004. Primary consumers and particulate organic matter: isotopic evidence of

12 strong selectivity in the estuarine transition zone. Limnology and Oceanography 49:

$13 \quad 1679-1686$.

14 McIver, Reba, Inka Milewski, and Heike K. Lotze. 2015. Land use and nitrogen loading

15 in seven estuaries along the southern Gulf of St. Lawrence, Canada. Estuarine,

16 Coastal and Shelf Science 165: 137-148.

17 Not, C., C. Hillaire-Marcel, B. Ghaleb, L. Polyak, D. Darby. $2008 .{ }^{210} \mathrm{~Pb}-{ }^{226} \mathrm{Ra}-{ }^{230} \mathrm{Th}$

18 systematics in very low sedimentation rate sediment report from the Mendeleev

19 Ridge (Actic Ocean). Canadian Journal of Earth Sciences. 45: 1207-1219.

20 Ock, G. and Y. Takemon. 2014. Effect of reservoir-derived plankton released from dams

21 on particulate organic matter composition in a tailwater river (Uji River, Japan):

22 Source partitioning using stable isotope of carbon and nitrogen. Ecohydrology 7:

$23 \quad 1172-1186$. 
1 Paerl, H. W., L. M. Valdes, J. L. Pinckney, M. F. Piehler, J. Dyble, and P. H. Moisander.

2 2003. Phytoplankton photopigments as indicators of estuarine and coastal

3 eutrophication. BioScience 53: 953-964.

4 Paerl, Hans W., Nathan S. Hall, and Elizabeth S. Calandrino. 2011. Controlling harmful

5 cyanobacterial blooms in a world experiencing anthropogenic and climatic-induced

6 change. Science of the Total Environment 409: 1739-1745.

7 Paerl, Hans W., Nathan S. Hall, Benjamin L. Peierls, Karen L. Rossignol, and Alan R.

8 Joyner. 2014. Hydrologic variability and its control of phytoplankton community

9 structure and function in two shallow, coastal, lagoonal ecosystems: the Neuse and

10 New River Estuaries, North Carolina, USA. Estuaries and Coasts 37: 31-45.

11 Peterson, B.J., and B. Fry. 1987. Stable isotopes in ecosystem studies. Annual Review of 12 Ecology and Systematics 18: 293-320.

13 Petersen, J. H., R. Reisenbichler, G. R. Gelfenbaum, C. Peterson, D. Baker, P. R. Leavitt, 14 C. A. Simenstad, and F. G. Prahl. 2003. Historical changes in the Columbia River 15 estuary based on sediment cores: feasibility studies. USGS Columbia River Estuary

16 Cores Final Report. 75 pp.

17 Phlips, Edward J., Susan Badylak, Mary C. Christman, and Margaret A. Lasi. 2010.

18 Climatic trends and temporal patterns of phytoplankton composition, abundance,

19 and succession in the Indian River lagoon, Florida, USA. Estuaries and Coasts 33:

$20 \quad 498-512$.

21 R Core Team. 2014. R: A language and environment for statistical computing. R

22 Foundation for Statistical Computing, Vienna, Austria. URL http://www.R-

23 project.org/ 
1 Rene Garcia, P.E. 2016. Hydraulic Design Manual. Texas Department of Transportation

2 http://onlinemanuals.txdot.gov/txdotmanuals/hyd/hydraulics_of_bridge_openings.h

$3 \quad \mathrm{tm}$

4 Reuss, N., D.J. Conley, and T.S. Bianchi. 2005. Preservation conditions and the use of

5 sediment pigments as a tool for recent ecological reconstruction in four northern

6 European estuaries. Marine Chemistry 95: 283-302.

7 Robichaud, Donat. 1976. Le Grand Chipagan: Histoire de Shippagan. Beresford : D.

$8 \quad$ Robichaud.

9 Rodrigues, Elsa T., and Miguel Â. Pardal. 2015. Primary productivity temporal

10 fluctuations in a nutrient-rich estuary due to climate-driven events. Estuaries and

$11 \quad$ Coasts 38: 1-12.

12 Rosenberg, D.M., Berkes, F., Bodaly, R.A., Hecky, R.E., Kelly, C.A., Rudd, J.W.M.,

13 1997. Large-scale impacts of hydroelectric development. Environmental Reviews 5:

$14 \quad 27-54$.

15 Savage C. 2005. Tracing the influence of sewage nitrogen in a coastal ecosystem using 16 stable nitrogen isotopes. Ambio 34: 143-148.

17 Savage C., R. Elmgren, and U. Larsson. 2002. Effects of sewage-derived nutrients on an 18 estuarine macrobenthic community. Marine Ecology Progress Series 243: 67-82.

19 Savage, C., P.R. Leavitt, R. Elmgren. 2010. Effects of land use, urbanization and climate

20 variability on coastal eutrophication in the Baltic Sea. Limnology and

21 Oceanography 55: 1033-1046. 
1 Serieyssol, C.A., M.B. Edlund, L.W. Kallemeyn. 2009. Impacts of settlement, damming

2 and hydromanagement in two boreal lakes: a comparative paleolimnological study.

3 Journal of Paleolimnology 42: 497-513.

4 Small, Christopher, and Robert J. Nicholls. 2003. A global analysis of human settlement 5 in coastal zones. Journal of Coastal Research 19: 584-599.

6 Statistics Canada. 2017. Shippagan, TV [Census subdivision], New Brunswick and

7 Gloucester, CT [Census division], New Brunswick (table). Census Profile. 2016

8 Census. Statistics Canada Catalogue no. 98-316-X2016001. Ottawa. Released May

9 3, 2017. http://www12.statcan.gc.ca/census-recensement/2016/dp-

10 pd/prof/index.cfm?Lang=E (accessed July 7, 2017).

11 Sterner, Robert W., Tom Andersen, James J. Elser, Dag O. Hessen, James M. Hood,

12 Edward McCauley, and Jotaro Urabe. 2008. Scale-dependent carbon: nitrogen:

13 phosphorus seston stoichiometry in marine and freshwaters. Limnology and

14 Oceanography 53: 1169-1180.

15 Surette, C., G. L. Brun, and V. N. Mallet. 2002. Impact of a commercial peat moss

16 operation on water quality and biota in a small tributary of the Richibucto River,

17 Kent County, New Brunswick, Canada. Archives of Environmental Contamination

18 and Toxicology 42: 423-30.

19 Tas, Seyfettin, I. Noyan Yilmaz, and Erdogan Okus. 2009. Phytoplankton as an indicator

20 of improving water quality in the Golden Horn Estuary. Estuaries and Coasts 32:

$21 \quad 1205-1224$. 
1 Taylor, David I., Candace A. Oviatt, and David G. Borkman. 2011. Non-linear responses

2 of a coastal aquatic ecosystem to large decreases in nutrient and organic loadings.

$3 \quad$ Estuaries and Coasts 34: 745-757.

4 ter Braak, Cajo JF, and Petr Šmilauer. 2002. CANOCO Reference manual and Canodraw

5 for Windows user's guide: software for canonical community ordination (version

6 4.5). www. canoco.com.

7 Tue, Nguyen Tai, Tran Dang Quy, Hideki Hamaoka, Mai Trong Nhuan, and Koji Omori.

8 2012. Sources and exchange of particulate organic matter in an estuarine mangrove

9 ecosystem of Xuan Thuy National Park, Vietnam. Estuaries and Coasts 35: 1060-

$10 \quad 1068$.

11 Turner, R. E., N. N. Rabalais, B. Fry, N. Atilla, C. S. Milan, J. M. Lee, C. Normandeau,

12 T. A. Oswald, E. M. Swenson, and D. A. Tomasko. 2006. Paleo-Indicators and

13 water quality change in the Charlotte Harbor Estuary (Florida). Limnology and

14 Oceanography 51: 518-533.

15 Vaalgamaa, Sanna, Eloni Sonninen, Atte Korhola, and Kaarina Weckström. 2013.

16 Identifying recent sources of organic matter enrichment and eutrophication trends

17 at coastal sites using stable nitrogen and carbon isotope ratios in sediment cores.

18 Journal of paleolimnology 50: 191-206.

19 Warner, B.G., and Pierre Buteau. 2000. The early peat industry in Canada, 1864-1945.

$20 \quad$ Geoscience Canada 27: 57-66.

21 Waters, Matthew N., Michael F. Piehler, Joseph M. Smoak, and Thomas S. Bianchi.

22 2012. Algal community responses to shallow lake dystrophication. Canadian

23 Journal of Fisheries and Aquatic Sciences 69: 1433-1443. 
1 Zelazny, Vincent Frank, Dept. of Natural Resources New Brunswick, and Ecosystem

2 Classsification Working Group. 2007. Our landscape heritage: the story of

3 ecological land classification in New Brunswick. Fredericton: New Brunswick

4 Dept. of Natural Resources. 
1 Table 1 Continuous rate of supply (CRS)-estimated age according to the mid-point of the 2 sediment intervals with lower and upper limit of the defined time period used to 3 aggregate yearly meteorological data

\begin{tabular}{lcccccc}
\hline \multicolumn{1}{c}{ Site } & $\begin{array}{c}\text { Sediment } \\
\text { interval } \\
(\mathrm{cm})\end{array}$ & $\begin{array}{c}\text { Mid- } \\
\text { point }\end{array}$ & $\begin{array}{c}\text { Lower year } \\
\text { limit for data } \\
\text { aggregation }\end{array}$ & $\begin{array}{c}\text { Upper } \\
\text { limit }\end{array}$ & $\begin{array}{c}\text { Time } \\
\text { period }\end{array}$ & $\begin{array}{c}\text { Estimated } \\
\text { year, based on } \\
\text { CRS model } \\
\text { (CE) }\end{array}$ \\
\hline Shippagan & $0-2$ & 1 & 2001 & 2012 & P4 & 2007 \\
northwest & $2-4$ & 3 & 1985 & 2000 & P3 & 1996 \\
("outer") & $4-6$ & 5 & 1955 & 1984 & P2 & 1975 \\
& $6-8$ & 7 & 1916 & 1954 & P1 & 1935 \\
& $8-10$ & 9 & & & & 1893 extrap. \\
Shippagan & $0-2$ & 1 & 2002 & 2012 & P7 & 2005 \\
east & $2-4$ & 3 & 1993 & 2001 & P6 & 1998 \\
("inner") & $4-6$ & 5 & 1983 & 1992 & P5 & 1988 \\
& $6-8$ & 7 & 1970 & 1982 & P4 & 1978 \\
& $8-10$ & 9 & 1953 & 1969 & P3 & 1963 \\
& $10-12$ & 11 & 1940 & 1952 & P2 & 1944 \\
& $12-14$ & 13 & 1932 & 1939 & P1 & 1936 \\
\hline
\end{tabular}

4 


\section{Figure captions}

2 Fig. 1 Map of Shippagan area showing the 1959 bridge that divided the bay in an outer

3 bay (northwest) and an inner bay (southeast), the two coring sites (full dots), the port

4 (circle), the municipal effluent discharge point (star) and roads (lines)

5 Fig. 2 Vertical profiles of ${ }^{210} \mathrm{~Pb}$ activity (left column) and Continuous Rate of Supply

6 model ages (right column) for the outer bay (top row) and inner bay (bottom row)

7 Fig. 3 Algal pigment concentration vertical profiles in the outer bay along depth $(\mathrm{cm})$ on

8 the primary axis and CRS-derived years on the secondary axis. Pigments includes: $\beta$ -

9 carotene, chlorophyll $a$ (all plants), fucoxanthin, diatoxanthin (diatoms), echinenone,

10 lutein-zeaxanthin, canthaxanthin (cyanobacteria), chlorophyll $b$ (Plantae, Chlorophyta,

11 Eugluenophyta) and alloxanthin (cryptophytes). Also shown are the chlorophyll $a$ to

12 pheophytin $a$ ratio (an index of preservation), and sediment organic content (\% of dry

13 mass)

14 Fig. 4 Same as Fig. 3, but for the inner bay

15 Fig. 5 Vertical age profiles of sedimentary (a) C:N ratio (b) $\delta^{13} \mathrm{C}$, (c) $\delta^{15} \mathrm{~N}$, (d) for

16 Shippagan northwest "outer bay" (dashed-line with black upright triangle) and

17 southeast "inner bay" (solid-line with black inverted triangle) (d) Biplot of $\delta^{13} \mathrm{C}$ and

$18 \delta^{15} \mathrm{~N}$ shows how outer bay samples (triangles) cluster apart from inner bay samples

19 (squares connected through time)

20 
1 Fig. 6 Principal component analysis biplot of outer bay (a), inner bay (b), and pooled (c)

2 core pigment community composition, with pigment as "species" vectors, and depths

3 (cm) as objects; CRS-estimated years for topmost depths $(1-9 \mathrm{~cm})$ are also indicated.

4 Sib: Shippagan “inner” bay (1944, 1963, 1988 surrounded by dashed line); Sob:

5 Shippagan “outer” bay

6 Fig. 7 Redundancy analysis of the outer bay fossil pigment community as a function of

7 April air temperature; fraction of inertia explained by the single canonical axis: $62 \%$

$8 \quad(\mathrm{p}=0.04)$

9 Fig. 8 Conceptual diagram showing how documented historical events (dashed-outline

10 boxes) may have influenced observed trends in phytoplankton abundance and

11 geochemical indicators (bold-outline boxes) via presumed modifications in water flow

12 and color (plain boxes)

13 
1 Online Resource 1 Timeline of selected events that potentially influenced the ecology of 2 Shippagan Bay or that characterized Shippagan's urban and industrial development. 3 Information relating to boardwalk construction and wastewaters is from Valmond 4 Doiron, Shippagan Municipal Engineer (pers. comm. 2016-06-29, 2017-01-12). 5 Population numbers were compiled from Statistics Canada. Other sources are indicated, 6 or from Robichaud (1976), Mallet (2012)

7

8 Online Resource 2 Sub-surface water quality at coring sites on coring date August $1^{\text {st }}$, $9 \quad 2012$ 
Fig. 1

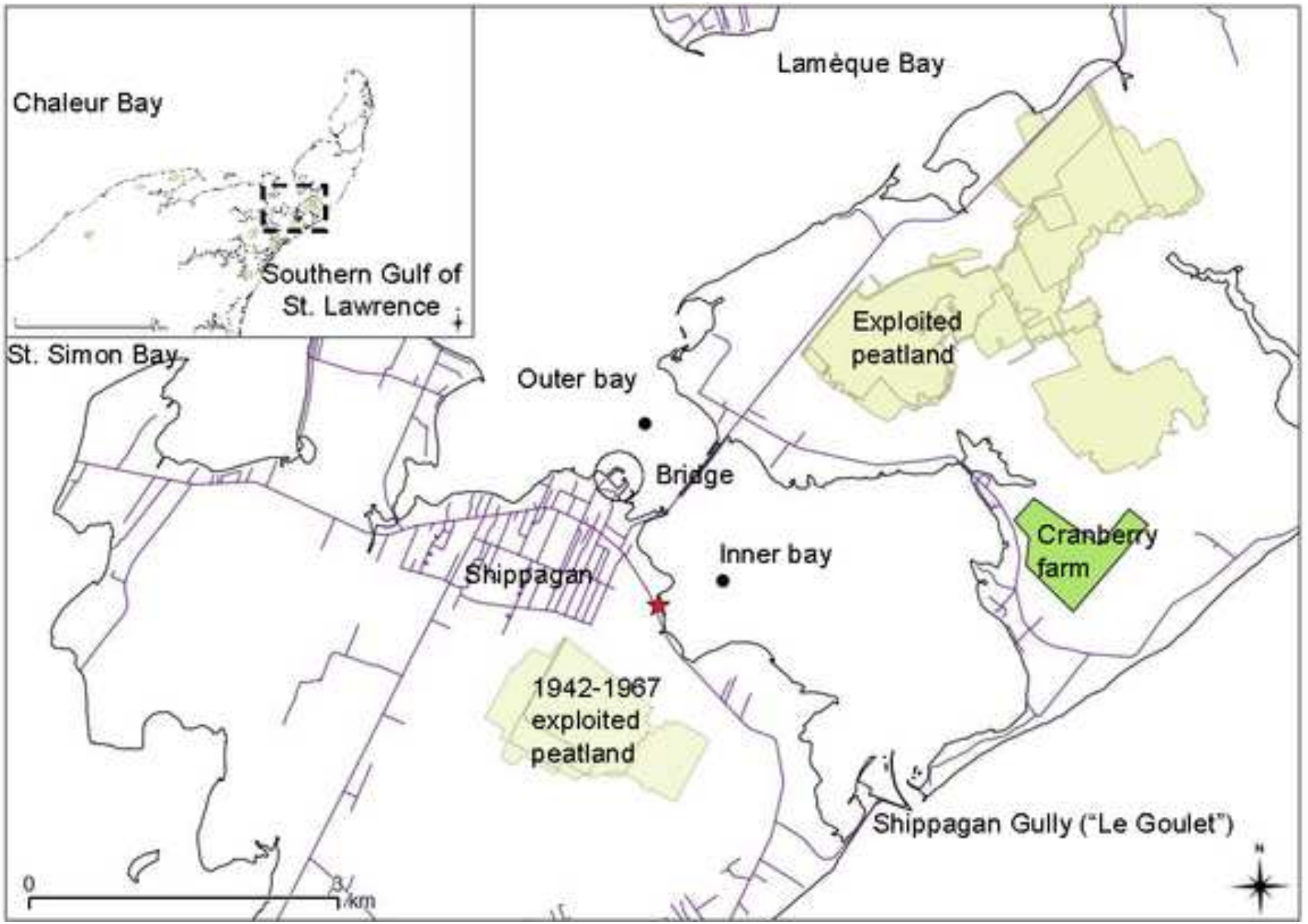


Fig. 2 a)

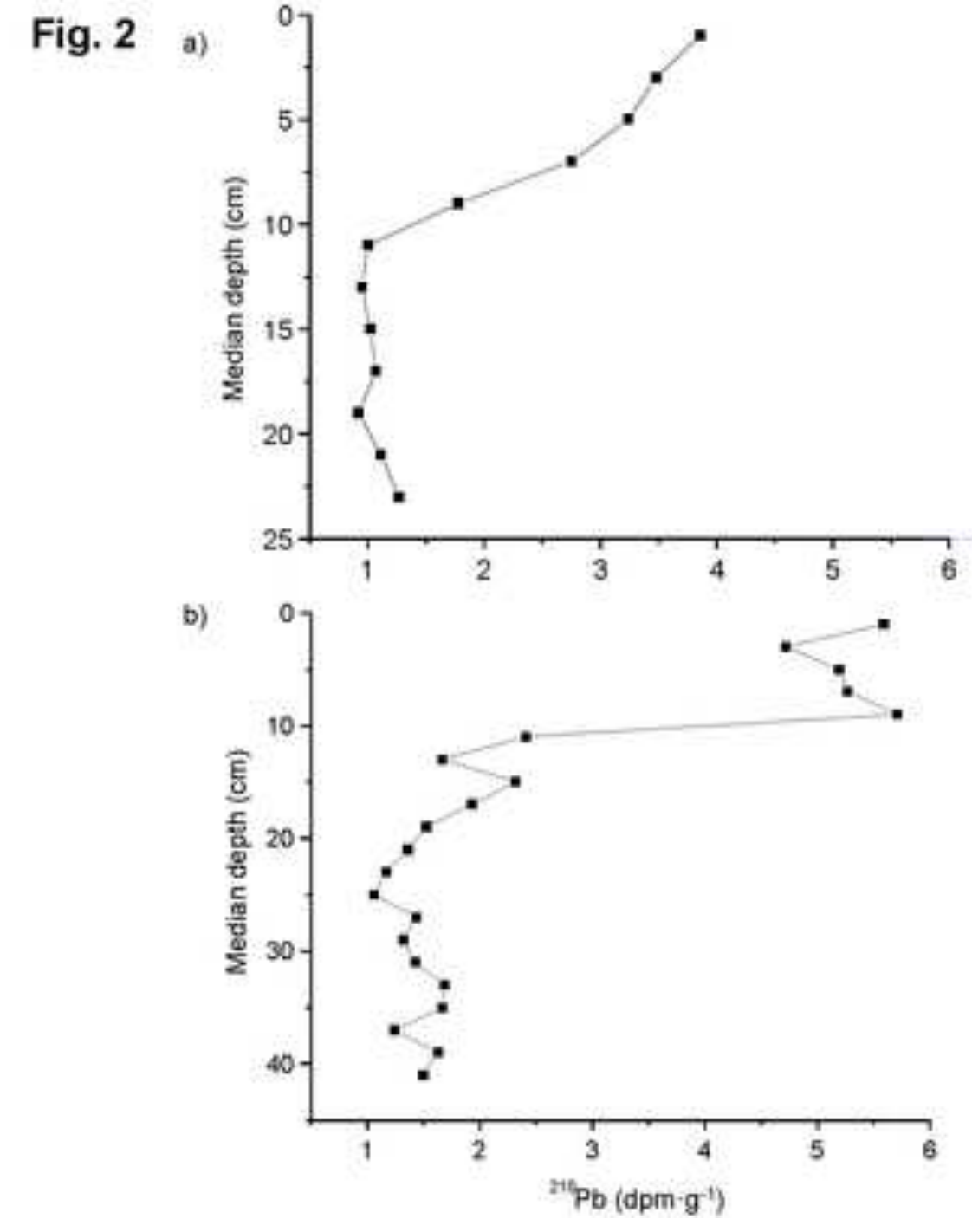

b)

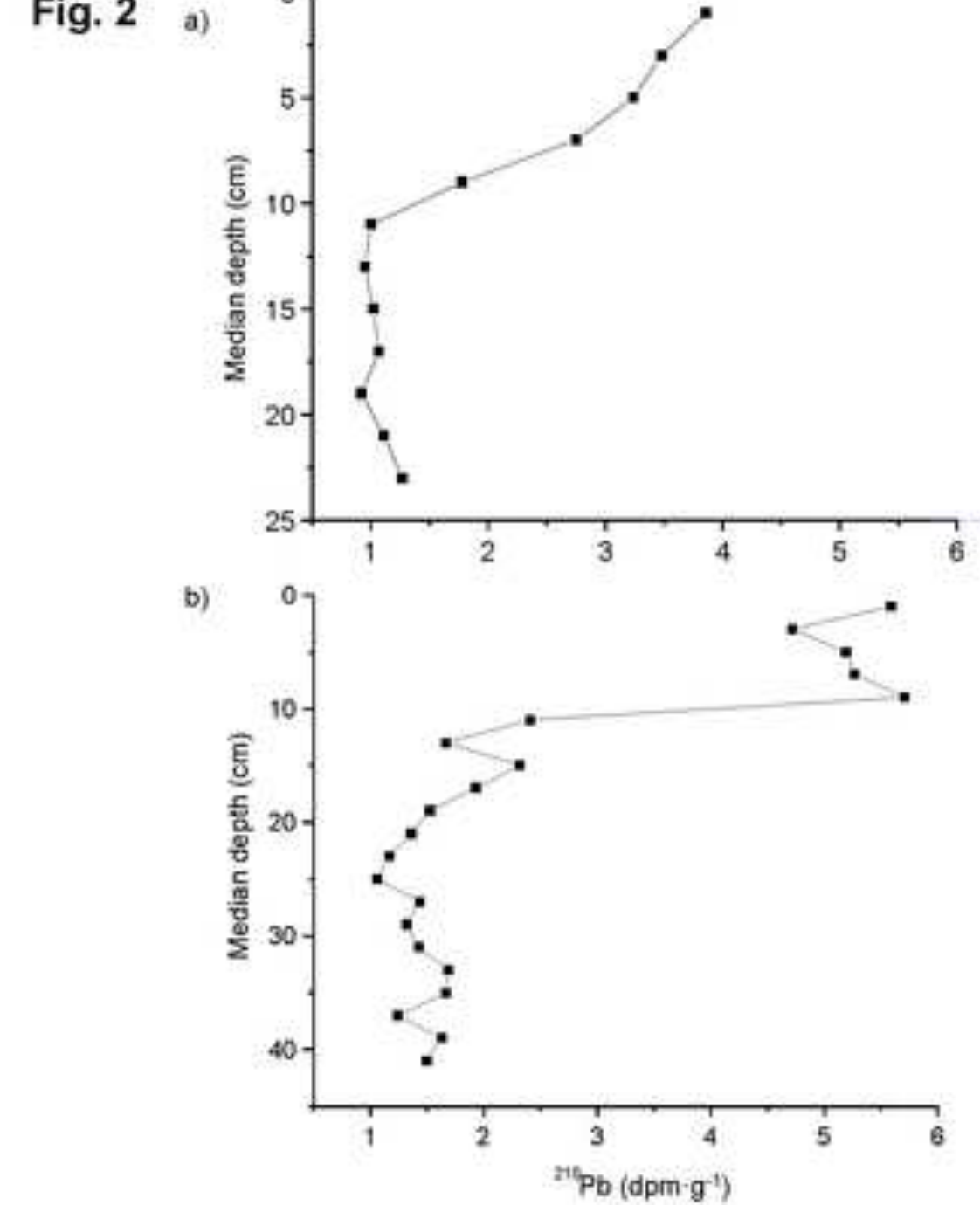

c)

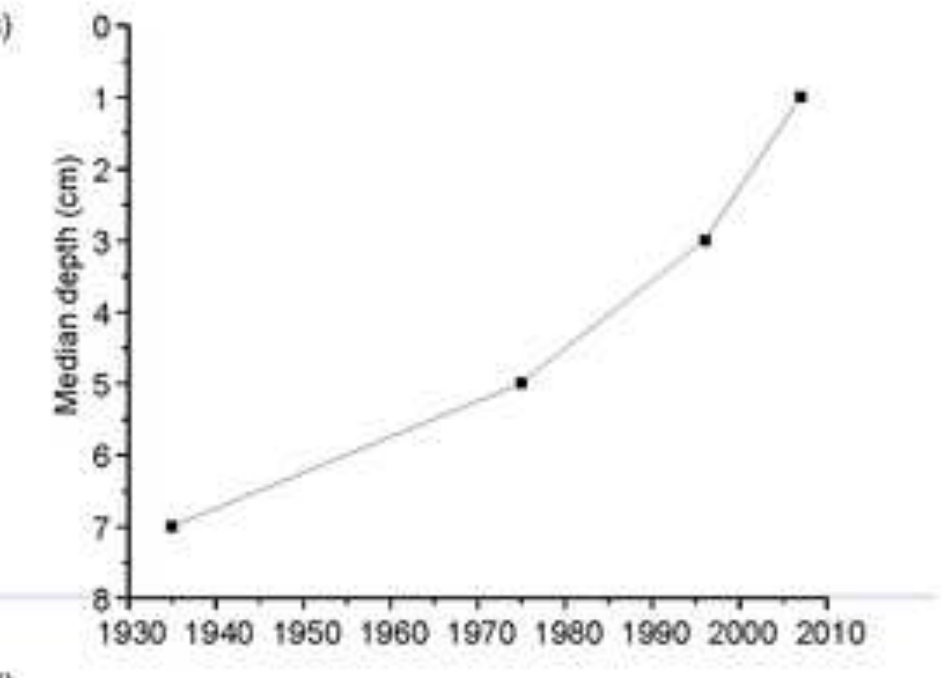

d)

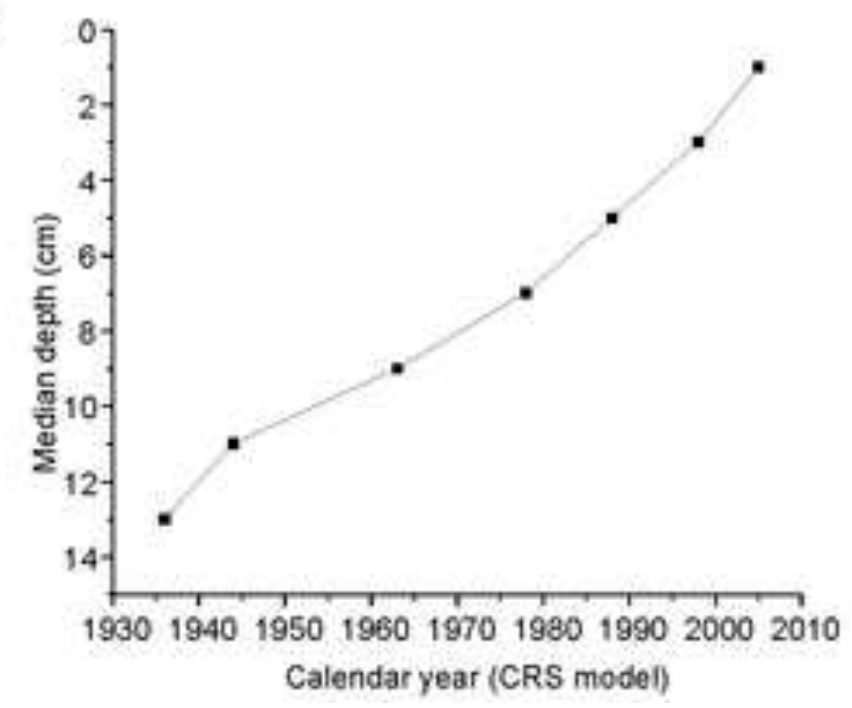

$$
\text { Calendar year (CRS model) }
$$

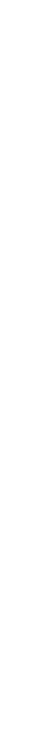

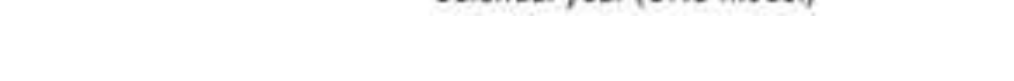


Fig. 3

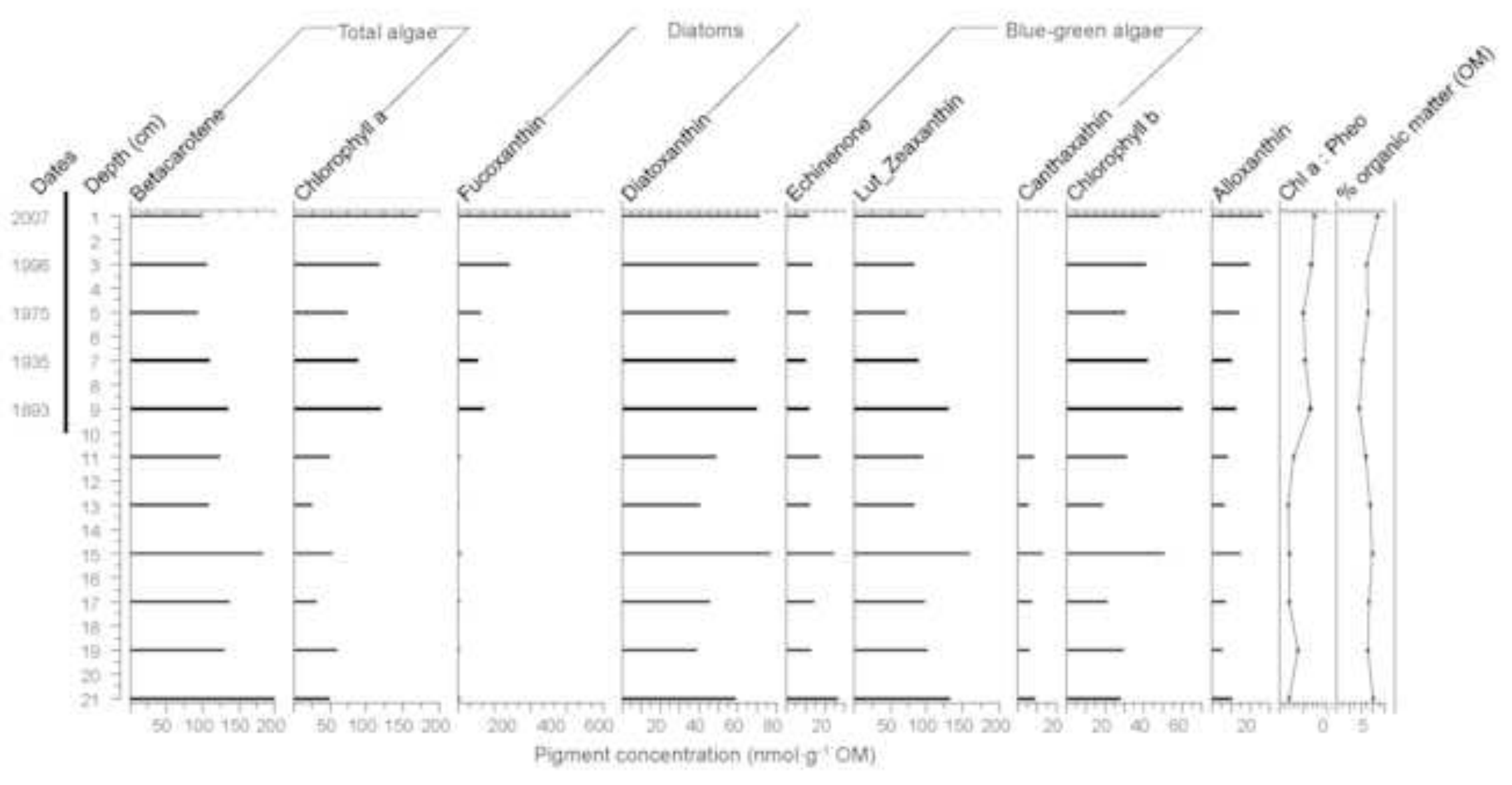


Fig. 4

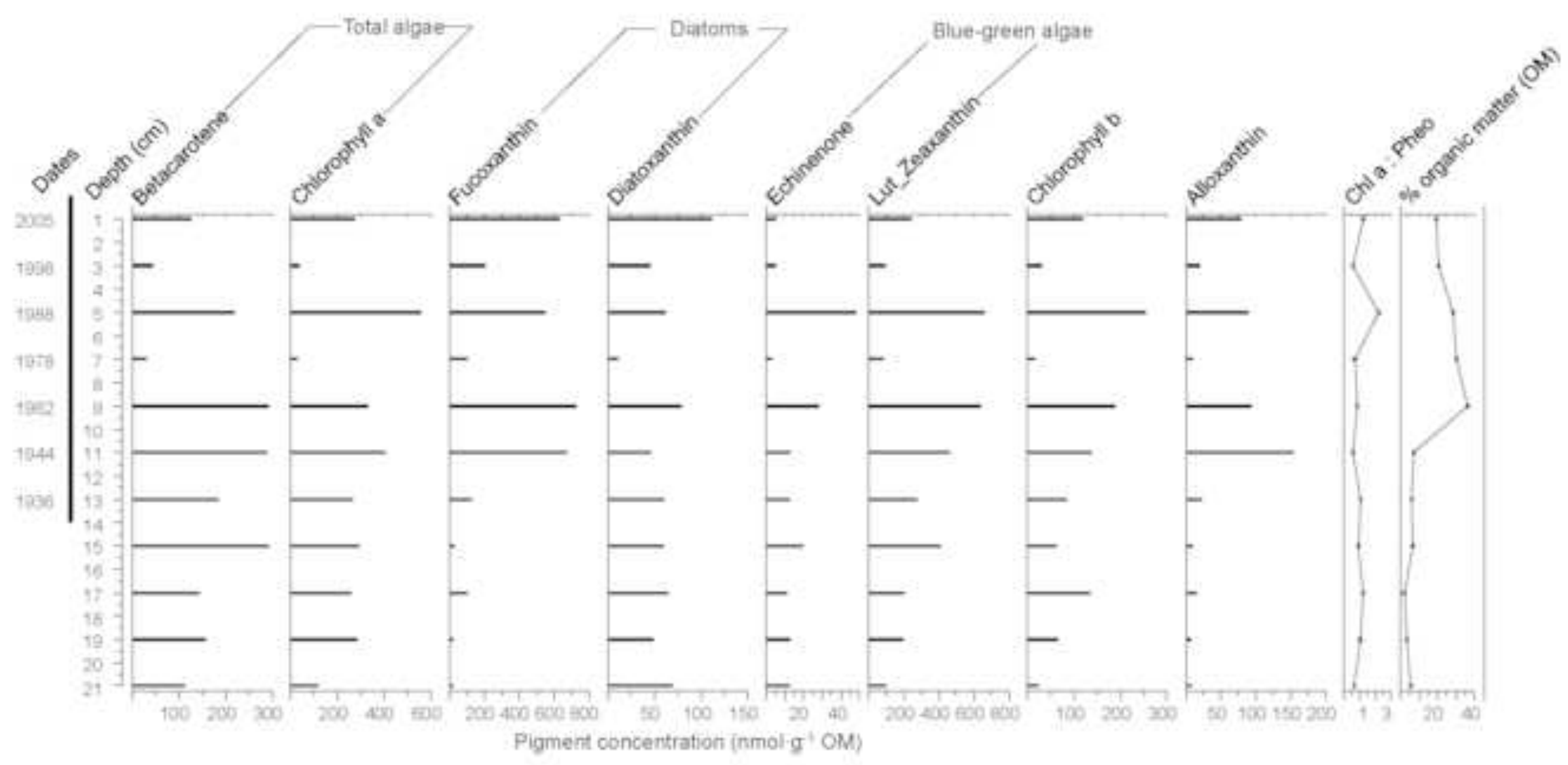


Fig. 5
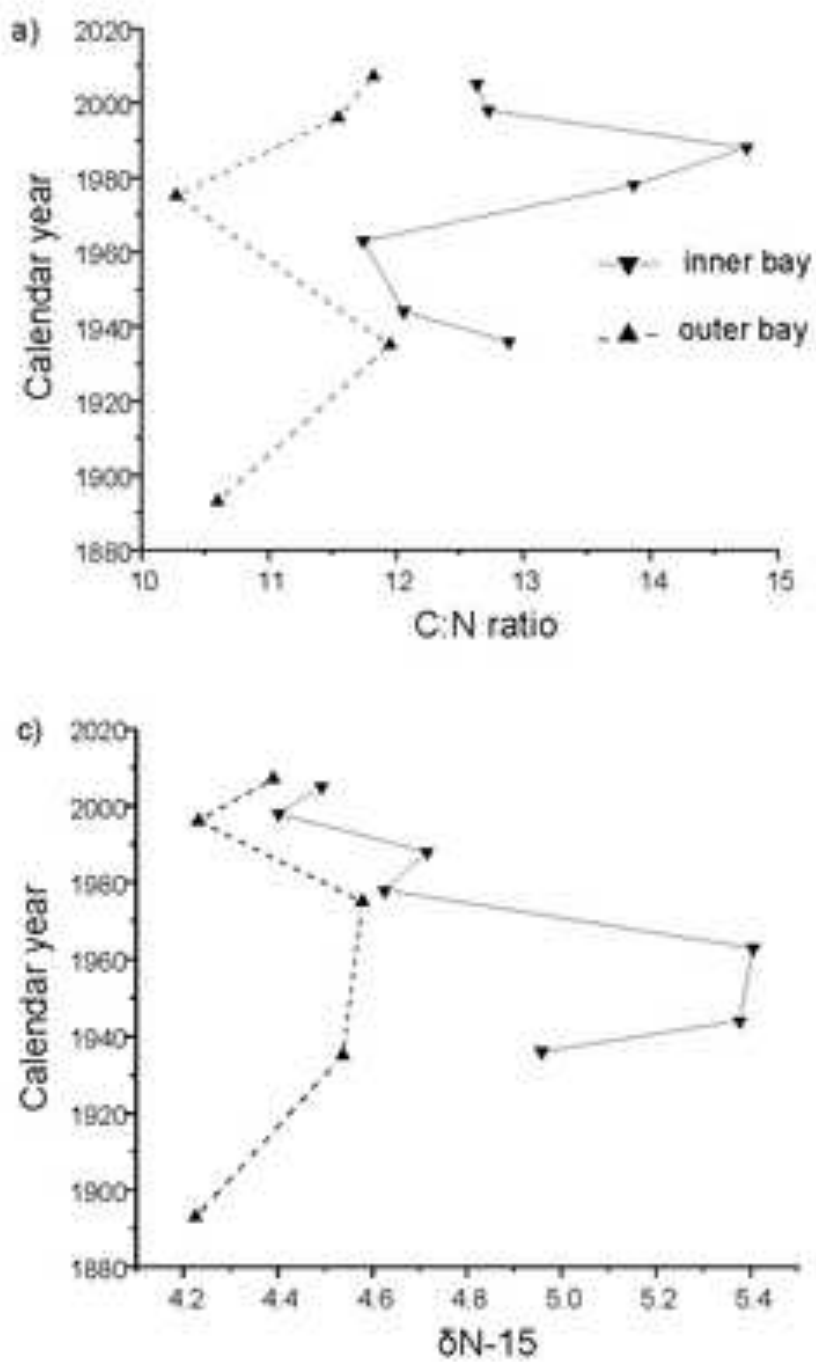

b) 202

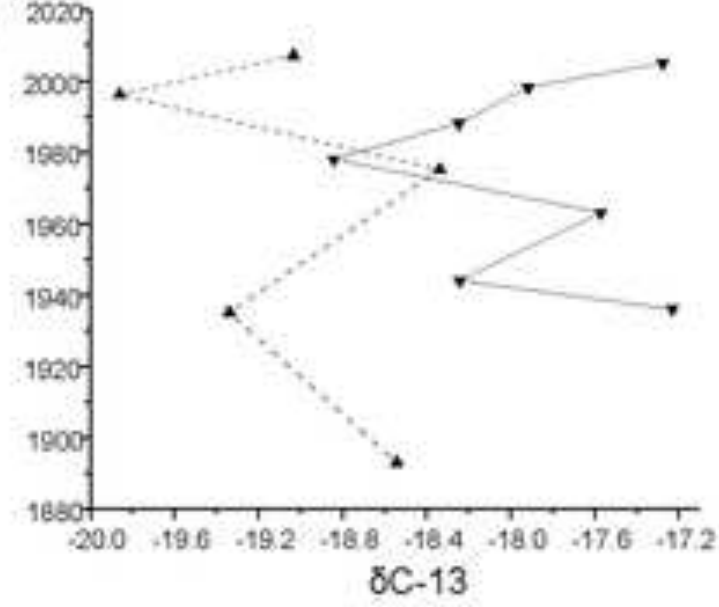

d)

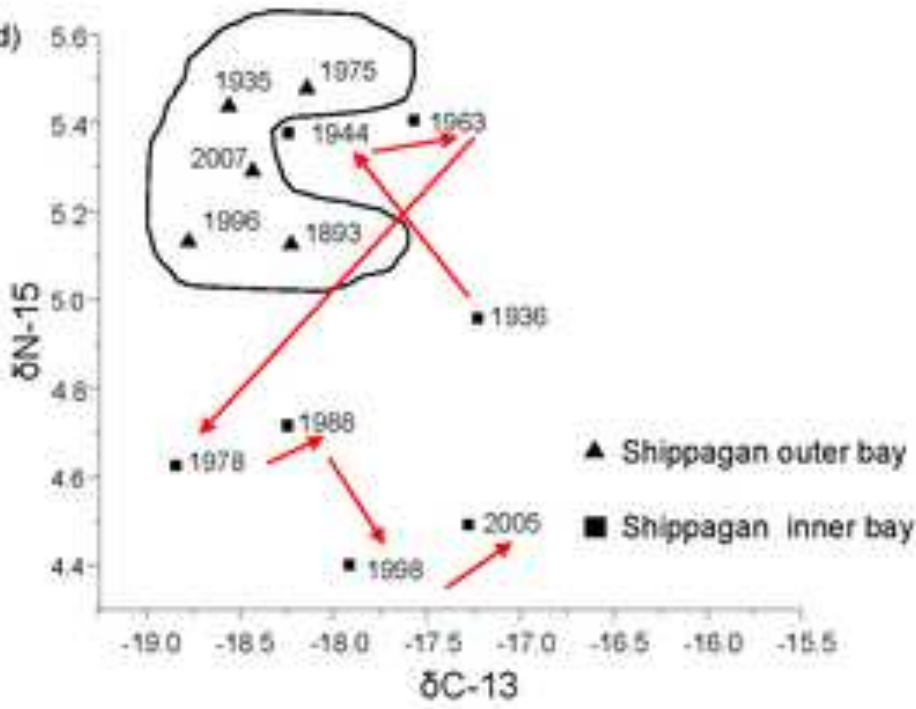


Fig. 6

a) Shippagan outer bay

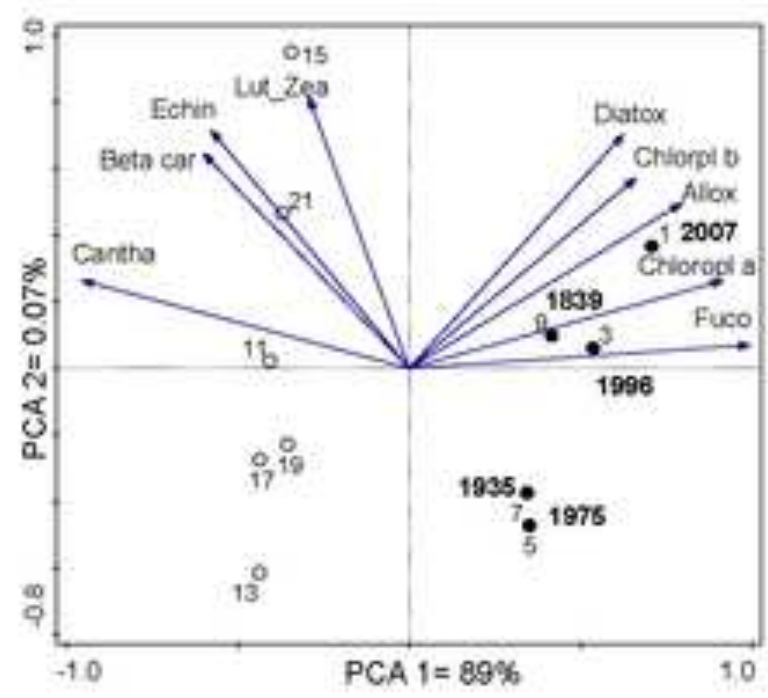

b) Shippagan inner bay

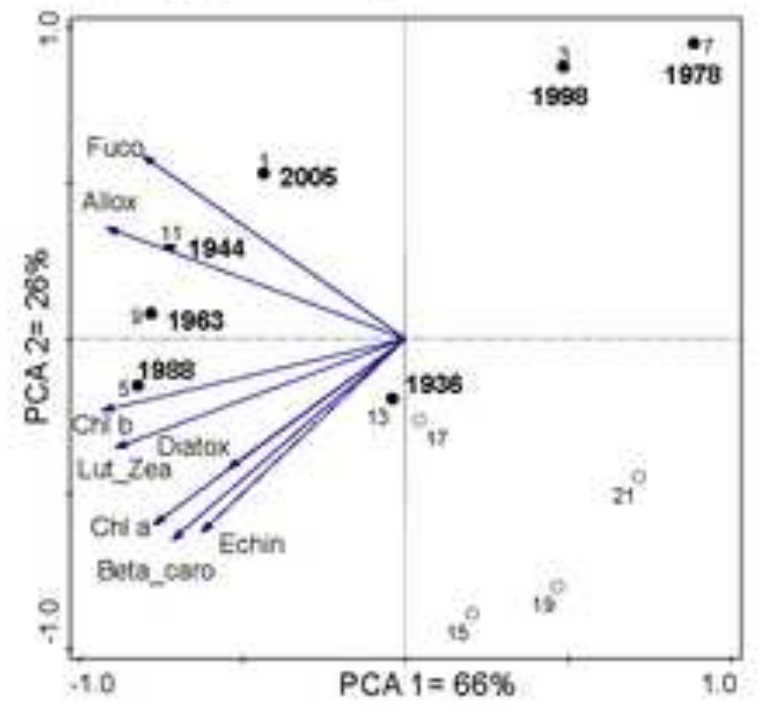

c) Shippagan outer (Sob) and inner (Sib) bay

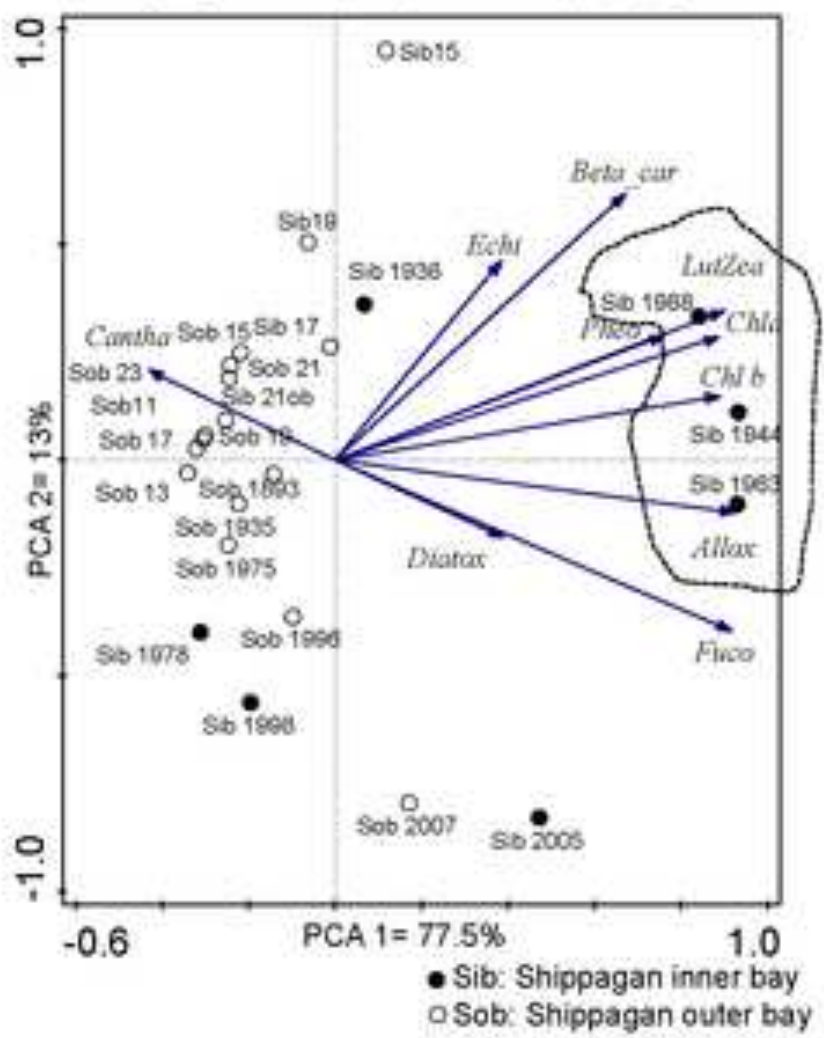




\section{Fig. 7}

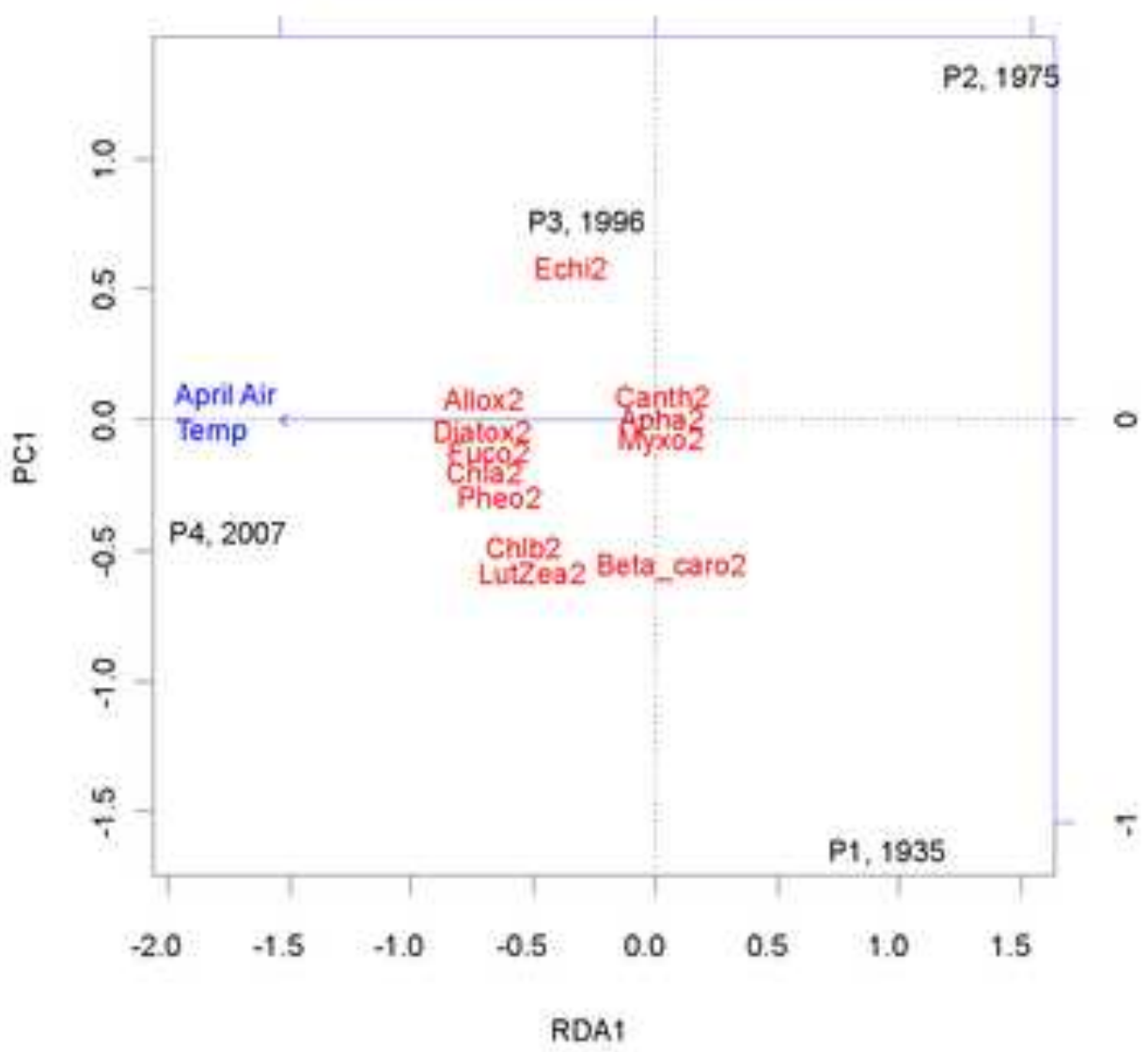


Fig. 8

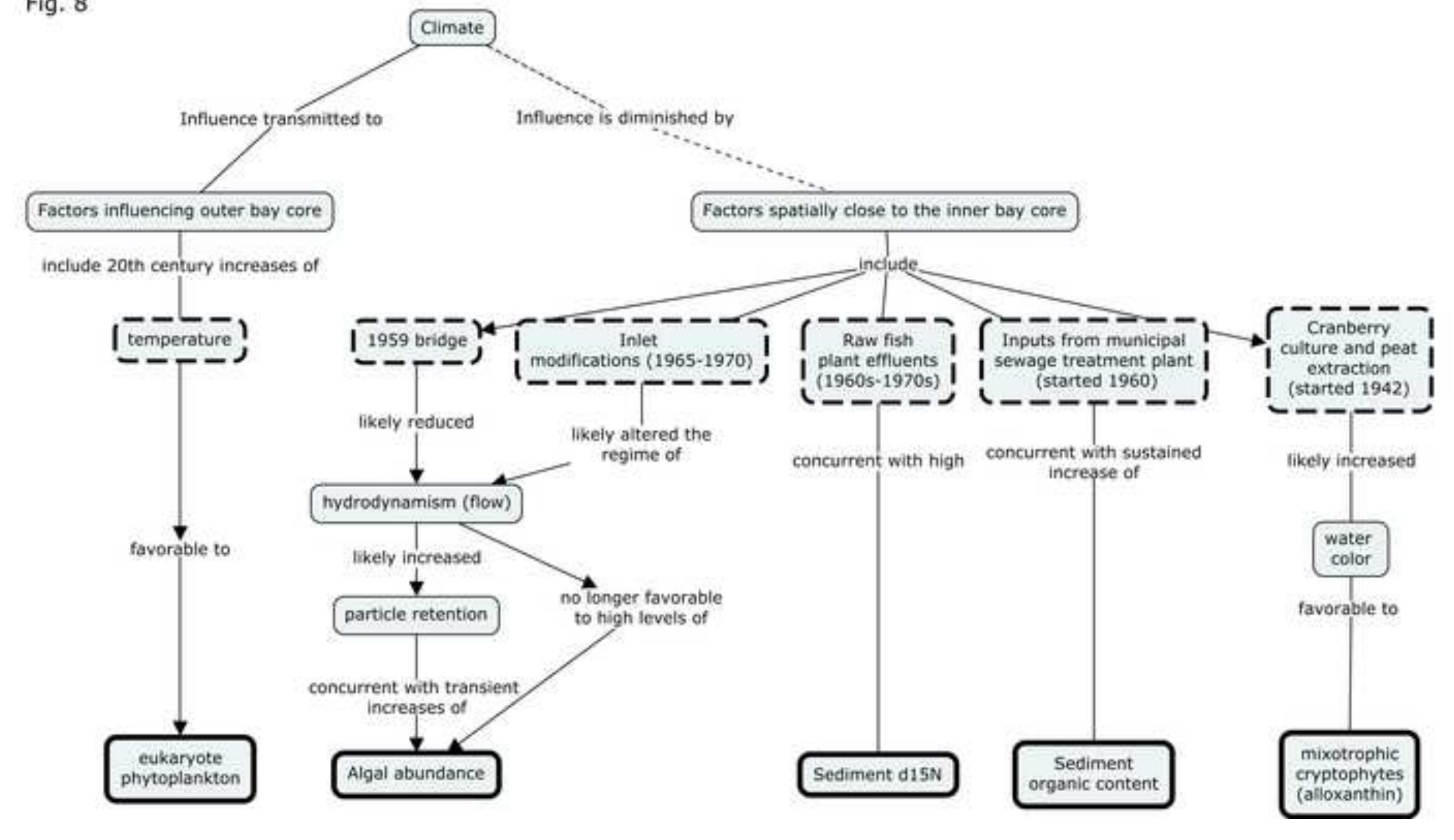

Influence is diminished by 
Online Resource 1 Timeline of selected events that potentially influenced the ecology of Shippagan Bay or that characterized Shippagan's urban and industrial development. Information relating to boardwalk construction and wastewaters is from Valmond Doiron, Shippagan Municipal Engineer (pers. comm. 2016-06-29, 2017-01-12). Population numbers were compiled from Statistics Canada. Other sources are indicated, or from Robichaud (1976), Mallet (2012)

\begin{tabular}{llll}
\hline Period & Shippagan as a whole & $\begin{array}{l}\text { Shippagan northwest } \\
\text { (NW) of the 1959 bridge } \\
\text { ("outer bay") }\end{array}$ & $\begin{array}{l}\text { Shippagan southeast (SE) of the } \\
1959 \text { bridge ("inner bay") }\end{array}$ \\
\hline $\begin{array}{l}19^{\text {th }} \\
\text { century to }\end{array}$ & $\begin{array}{l}\text { Domestic wastewaters } \\
\text { through "straight pipes" } \\
\text { in the bay or to septic } \\
\text { tanks. }\end{array}$ & \\
\hline $1950 \mathrm{~s}$ & & $\begin{array}{l}\text { "Construction of two 300 m } \\
\text { jetties (...) on either side of the } \\
\text { inlet" to help navigation (Logan } \\
\text { 2012: 76). }\end{array}$ \\
\hline
\end{tabular}

$\begin{array}{ll}\text { 1898-1906 } & \begin{array}{l}\text { Completion of the public } \\ \text { wharf. }\end{array}\end{array}$

\begin{tabular}{ll}
\hline 1942-1945 & $\begin{array}{l}76 \text { ha peat extraction southwest } \\
\text { of bay begins; } 268 \mathrm{Mg} \\
\text { produced in } 1942 \text { (Warner and } \\
\text { Buteau 2000). }\end{array}$ \\
\hline 1955 & $\begin{array}{l}61 \text { ha peat extraction begins } \\
\text { northeast of bay. }\end{array}$
\end{tabular}

\begin{tabular}{lll}
\hline $1957-1959$ & Bridge construction. & \\
\hline $\begin{array}{l}1961, \\
\text { summer }\end{array}$ & $\begin{array}{l}\text { Shippagan municipality } \\
\text { population reaches 1631. }\end{array}$ & $\begin{array}{l}\text { First lagoon begins operation; } \\
\text { effluents are directed into inner } \\
\text { bay's "Baie Sauvage". }\end{array}$ \\
\hline $1965-1969$ & $\begin{array}{l}\text { Addition of a new 90-m jetty } \\
\text { stretching to the south-west on } \\
\text { the east side of the inlet (Logan } \\
\text { 2012). }\end{array}$
\end{tabular}




\begin{tabular}{|c|c|c|c|}
\hline Period & Shippagan as a whole & $\begin{array}{l}\text { Shippagan northwest } \\
\text { (NW) of the } 1959 \text { bridge } \\
\text { ("outer bay") }\end{array}$ & $\begin{array}{l}\text { Shippagan southeast (SE) of the } \\
1959 \text { bridge ("inner bay") }\end{array}$ \\
\hline $1966-1970$ & & & $\begin{array}{l}\text { Construction of a } 600 \mathrm{~m} \text { long } \\
\text { curved breakwater to promote } \\
\text { self-scouring of the navigation } \\
\text { channel. }\end{array}$ \\
\hline $\begin{array}{l}\text { 1960s- } \\
1970 \mathrm{~s}\end{array}$ & $\begin{array}{l}\text { Shippagan municipality } \\
\text { population reaches } 2069 \\
\text { in } 1971,2344 \text { in } 1976 .\end{array}$ & $\begin{array}{l}\text { Up to five fish } \\
\text { transformation plants } \\
\text { direct their untreated } \\
\text { effluents West of the } \\
\text { bridge. }\end{array}$ & $\begin{array}{l}\text { Two fish transformation plants } \\
\text { direct their untreated effluents } \\
\text { into the "inner bay", East of the } \\
\text { bridge. }\end{array}$ \\
\hline 1980s & $\begin{array}{l}\text { Shippagan municipality } \\
\text { population reaches } 2825 \\
\text { in } 1981 .\end{array}$ & & $\begin{array}{l}\text { Partial failure of lagoons to } \\
\text { comply with provincial } \\
\text { guidelines. }\end{array}$ \\
\hline 1986 & $\begin{array}{l}\text { Shippagan municipality } \\
\text { population decreases to } \\
2801 \text {. }\end{array}$ & & $\begin{array}{l}\text { Aerators are added to lagoon } \\
\text { no. } 2 \text { in April } 1986 .\end{array}$ \\
\hline $\begin{array}{l}1989 \text { and } \\
1993\end{array}$ & & & $\begin{array}{l}\text { Le Goulet Harbour dredging } \\
\text { (Logan 2012). }\end{array}$ \\
\hline $1998-2004$ & & & $\begin{array}{l}\text { Gradual collapse of the outer } \\
40 \text { m of the east jetty (Logan } \\
\text { 2012). }\end{array}$ \\
\hline $1998-2002$ & & $\begin{array}{l}\text { 2-km boardwalk } \\
\text { construction in the outer } \\
\text { bay. }\end{array}$ & $\begin{array}{l}\text { Cranberry culture begins near } \\
\text { northeast shore (Fig. 1) and } \\
\text { reaches } 47 \text { ha in } 2016 \text {. }\end{array}$ \\
\hline 2011 & $\begin{array}{l}\text { Shippagan municipality } \\
\text { population declines to } \\
\text { 2631; density: } 262 \mathrm{~km}^{-2} \text {; } \\
\text { dwellings: } 1199 .\end{array}$ & $\begin{array}{l}\text { Last fish transformation } \\
\text { plant closes down. }\end{array}$ & \\
\hline $2002-2015$ & & & $\begin{array}{l}\text { Average effluent flow from } \\
\text { Shippagan wastewater } \\
\text { treatment plant into Baie } \\
\text { Sauvage ("inner bay") is } 76 \\
\mathrm{~L} \cdot \mathrm{s}^{-1}(14 \text { to } 153) \text {, TP } 1.1 \mathrm{mg} \cdot \mathrm{L}^{-1} \\
(0.2-2.9), \mathrm{N}: \mathrm{P} \text { ratio } 7.6 \text { (by } \\
\text { mass). }\end{array}$ \\
\hline
\end{tabular}


Online Resource 2 Sub-surface water quality at coring sites on coring date August $1^{\text {st }}$, 2012

\begin{tabular}{lccccccccc}
\hline & $\begin{array}{c}\text { Temp. } \\
\left({ }^{\circ} \mathrm{C}\right)\end{array}$ & $\begin{array}{c}\text { Salinity } \\
(\%)\end{array}$ & $\begin{array}{c}\text { Turbidity } \\
(\mathrm{NTU})\end{array}$ & $\begin{array}{c}\text { Dissolved } \\
\text { Oxygen } \\
\left(\mathrm{mg} \cdot \mathrm{L}^{-1}\right)\end{array}$ & $\begin{array}{c}\mathrm{pH} \\
\text { Dissolved } \\
\text { organic } \\
\text { carbon } \\
\left(\mathrm{mg} \cdot \mathrm{L}^{-1}\right)\end{array}$ & $\begin{array}{c}\mathrm{TN} \\
\left(\mu \mathrm{g} \cdot \mathrm{L}^{-1}\right)\end{array}$ & $\begin{array}{c}\mathrm{TP} \\
\left(\mu \mathrm{g} \cdot \mathrm{L}^{-1}\right)\end{array}$ & $\begin{array}{c}\mathrm{Chl}-\mathrm{a} \\
\left(\mu \mathrm{g} \cdot \mathrm{L}^{-1}\right)\end{array}$ \\
\hline $\begin{array}{l}\text { Outer } \\
\text { Bay }\end{array}$ & 22 & 2.8 & 4 & 7.7 & 8.1 & 2.4 & $<300$ & 21 & 2.6 \\
$\begin{array}{l}\text { Inner } \\
\text { Bay }\end{array}$ & 23 & 2.8 & 6 & 7.7 & 8.1 & 2.6 & $<300$ & 42 & 5.5 \\
\hline
\end{tabular}

